\title{
Exploratory Study of the Development of REDD Incentives in Bolivia
}

\author{
Jannes Stoppel
}

This thesis was submitted in partial fulfilment of the Masters of Development Studies August 2008

School of Geography, Environment and Earth Sciences Victoria University of Wellington

Aotearoa - New Zealand

jannes.stoppel@me.com 


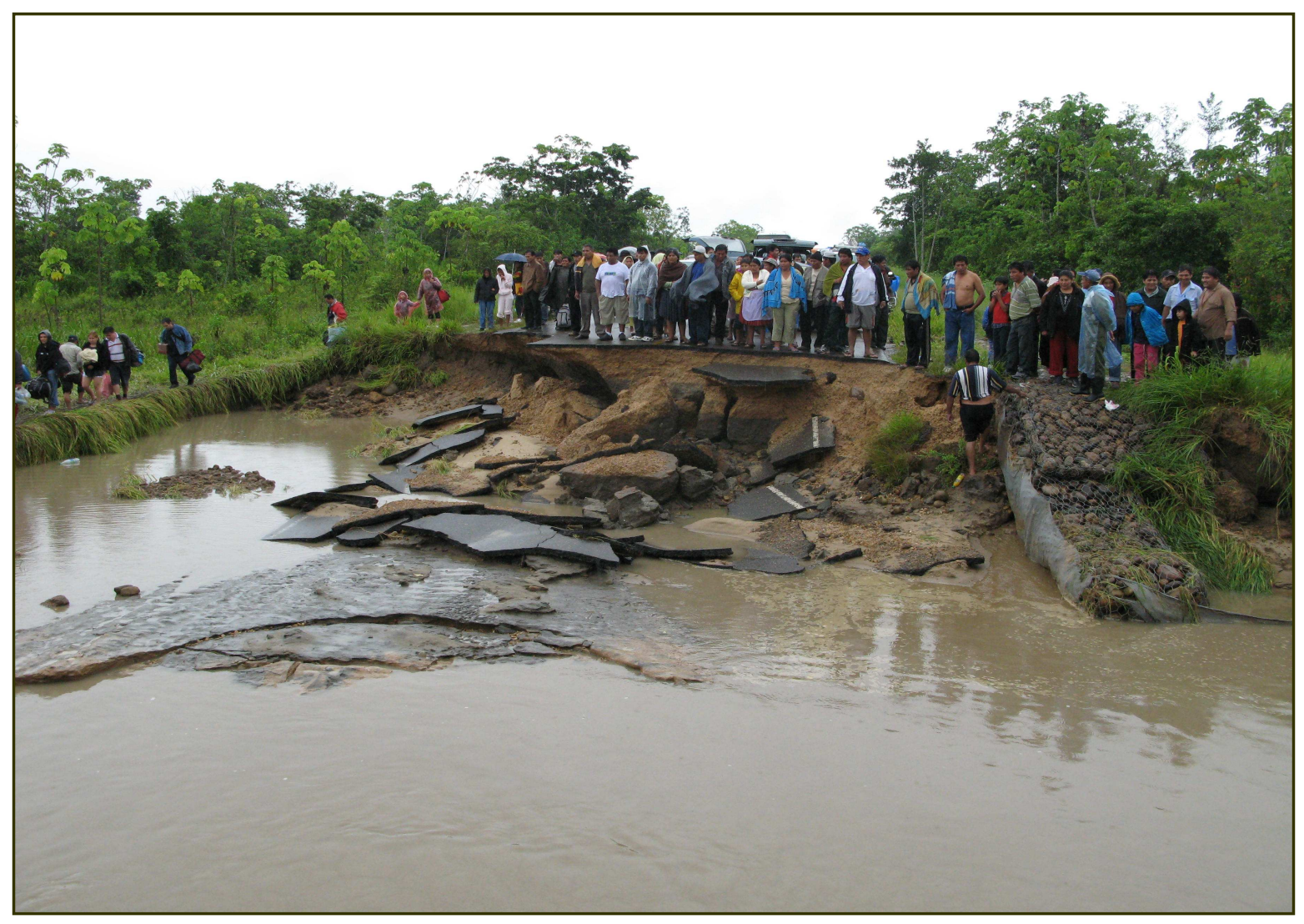

Effects of increasing climate irregularities in Bolivia

Photo taken by the author, January 2003, Santa Cruz, Bolivia 


\begin{abstract}
International climate change mitigation efforts have been establishing strategies and programs to achieve Reduction of Emissions from Deforestation and Degradation (REDD) in developing countries like Bolivia. This research aims to assess these developments and examine the major challenges in the conceptualisation, planning and implementation of these strategies in Bolivia. A review of international negotiations and of current literature on various surrounding issues supplied this research with the needed secondary data. Primary data on Bolivian perspectives and visions on the arising challenges of REDD developments were gathered in January and February 2008. The semi-structured interviews aimed to cover a cross societal range of participants from govt to local forest-inhabitant level. Partially, due to climatic instability, the field-research was hampered by a national flood disaster that challenged the gathering of local forest-inhabitant's visions and perspectives.

Through this methodology this research defined key issues in the development of international REDD funding governance and in the challenges of national and local policy and project implementation measures. These are evaluated in consideration of global and local equity and climate-justice issues, offer earthcentric considerations in the evolution of REDD and therefore attempt to contribute to the underlying discourse on ecological ethics in climate change mitigation and adaptation.
\end{abstract}

\title{
Keywords:
}

Reduction of Emissions from Deforestation and Forest Degradation, Bolivia, Ecological Ethics, Climate Change Ethics, Climate Justice, Global Equity 
For Earth

and

Future Generations 


\section{Appreciations}

\section{In Aotearoa}

I would like to thank my course-coordinator John Overton and my supervisor Warwick Murray for their guidance, trust, and support during this research project. Additionally I would like to thank especially Sean Weaver for inspiring me to take the path I took. The Moana girls for a beautiful home, my $72 \mathrm{a}$ KP Crew for doing it for the love of it, my fellow officers at the 'Ministry of hard work' and all others friends here in Wellington, for sharing this part of life with me. To Raoni and my crew in Otautahi, and Holger, Jenny and my whanau in Purau for grounding me in this time with all your wit and wisdom.

\section{Overseas}

I would like to thank Annika and my parents for their ongoing love and support. I would like to thank my friends who kept contact around the world.

The actors of climate change adaptation and mitigation are hereby honoured for their work and effort to create the seemingly impossible changes in a by exploitation and aggression dominated world with a reasonable mistrust between exploited and their exploiters, developing and overdeveloped societies. Shouts out to all activists, campaigners and to all people that stand up for a better future of of our children and the diversity of life on earth.

\section{In Bolivia}

I would like to thank Gisella Ulloa V. for her support to establish contacts in Bolivia, Jörg Seifert-Granzin und Dr. Rolf Wachholtz for sharing their expertise, Marco Octavio Ribera Arismendi for his inspiration and everybody else for their time and their contribution to this research. Thank you very much. I would also like to thank the Bolivian people for a wonderful time with many beautifully friendly encounters in this amazingly diverse country.

\section{And Above All.}

Many have contributed to this work, but any mistakes are my responsibility alone. 


\section{Contents}

\section{INTRODUCTION, AIMS AND OBJECTIVES}

1.1 INTRODUCTION

1.2 RESEARCH AIM

1.3 RESEARCH OBJECTIVES

1.4 THE STRUCTURE OF THIS RESEARCH

1.4.1 CHAPTER TWO

1.4.2 CHAPTER THREE

1.4.3 CHAPTER FOUR

1.4.4 CHAPTER FIVE

1.4.5 CHAPTER SIX

1.4.6 CHAPTER SEVEN

1.5 CONClusion

2.1 INTRODUCTION

2.2 Positionality

2.3 EPISTEMOLOGY

2.4 A DIRECT BARTER IDEOLOGY

2.5 WHY BOLIVIA?

2.6 Change OF Focus

2.7 METHODOLOGY

2.8 METHODS

2.9 PARTICIPATION OF INTERVIEWEES

2.10 SEMI-STRUCTURED INTERVIEWS

2.11 ETHICAL CONSIDERATIONS 17

2.12 ENCOUNTERED Problems 19

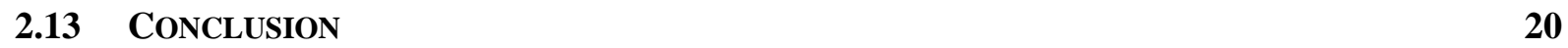

3. CLIMATE CHANGE MITIGATION AND DEFORESTATION

3.2 THE NEED TO REDUCE DEFORESTATION 22

3.3 DEFORESTATION, FOREST DEGRADATION AND GHG EMISSIONS 25

3.4 DEFINITION OF REDD

3.5 THE ESTABLISHMENT OF REDD STRATEGIES UNDER THE UNFCCC 27 
3.6 THE VALUE OF REDD INCENTIVES

3.7 THE FOREST CARBON PARTNERSHIP FACILITY

3.8 VISIONS FROM THE FORESTS

$\begin{array}{lll}3.9 & \text { CONCLUSION } & 37\end{array}$

4. BOLIVIA'S SOCIO-POLITICAL AND ENVIRONMENTAL SITUATION

4.1 BOLIVIA'S GEOGRAPHY

4.2 Political DeVelopMent

4.3 ECONOMIC PERSPECTIVES

4.4 BOLIVIAN FORESTS

4.5 THE FLOODS OF JANUARY 47

4.6 CONCLUSION

BOLIVIA'S REDD STRATEGIES

4.7 INTRODUCTION

4.8 BOlivia's Climate Change Strategy

4.9 BOLIVIA AND THE FCPF

4.10 THE READINESS ASSESSMENT

4.11 LOCAL PARTICIPATION IN BOLIVIAN REDD STRATEgIeS 56

4.12 A VIEW IN THE FUTURE

4.12.1 THE READINESS PLAN 57

4.12.2 THE CARBON FinANCE MECHANISM

$\begin{array}{lll}4.13 & \text { CONCLUSION } & 61\end{array}$

5. CHALLENGES IN THE ACHIEVEMENT OF REDD IN BOLIVIA

$\begin{array}{lll}5.1 & \text { INTRODUCTION } & 62\end{array}$

$\begin{array}{lll}5.2 & \text { BASIC NEEDS } & 62\end{array}$

5.3 VALUATION OF REDD

$\begin{array}{lll}5.4 & \text { COMMON VISION } & 65\end{array}$

5.5 PARTICIPATION 66

$\begin{array}{lll}5.6 & \text { INSTITUTIONAL CAPACITY AND CORRUPTION } & 67\end{array}$

$\begin{array}{lll}5.7 & \text { Political STABiLity } & 68\end{array}$

$\begin{array}{llr}5.8 \text { CONCLUSION } & 69\end{array}$

6. CONCLUDING THOUGHTS

$\begin{array}{lll}\text { 6.1 INTRODUCTION } & 70\end{array}$

6.2 BOLIVIA'S REDD STRATEGIES

6.3 REDD AND INTERNATIONAL Climate Change Negotiation 72

6.4 REDD BACK HOME $\quad 73$

6.5 FinAL REMARKS $\quad 74$

REFERENCES

\begin{tabular}{lr} 
ANNEXES & 83 \\
\hline
\end{tabular} 


\section{Acronyms}

$\begin{array}{ll}\text { UNFCCC } & \text { United Nations Framework Convention for Climate } \\ \text { IPCC } & \text { International Panels of Climate Change } \\ \text { PNCC } & \text { Bolivia's National Climate Change Programme } \\ \text { REDD } & \text { Reduction of Emissions from Deforestation and } \\ \text { Degradation } & \\ \text { FCPF } & \text { Forest Carbon Partnership Facility, facilitated by } \\ \text { the World Bank } & \\ \text { CRN } & \text { Coalition of Rainforest Nations or used as Nations } \\ \text { of the Rainforest Coalition } \\ \text { CDM } & \text { Clean Development Mechanisms } \\ \text { CCM } & \text { Climate Change Mitigation } \\ \text { CCA } & \text { Climate Change Adaptation } \\ \text { NGO } & \text { Non-Governmental Organizations } \\ \text { ICDP } & \text { Integrated Conservation and Development Project } \\ \text { ER } & \text { Emission Reduction } \\ \text { GHG } & \text { Greenhouse Gas } \\ \text { PES } & \text { Payments for Environmental Services } \\ \text { FPP } & \text { Forest Peoples Program }\end{array}$




\section{Introduction, Aims and Objectives}

\subsection{Introduction}

The pursuit of exponential economic growth by industrialised human societies has for decades partially ignored the need to care for the wellbeing of the earthsystem. The anthropocentric leadership of our species and the promotion of excessive egocentric consumer behaviours have failed to cautiously respect the web of complex interactions that form the basis of life on Earth as we know it. As called for by indigenous nations, environmental campaigns, the Brundtland Report and many others, the time for serious consideration of human induced impacts on the earthsystem are of enormous urgency. 'Humanity may be standing at a point in history when a great transformation is needed to respond to the immense threat to the Earth' (PICIR, 2007).

One way of reducing the global human footprint is the reduction of deforestation and the conservation of the last remaining oldgrowth forest habitats with all its biodiversity. Forest conservation offers a range of local and global benefits one of them being the reduction of greenhouse gas emissions (GHG), especially $\mathrm{CO}^{2}$. Soares-Filo et al. suggest that, under a business-as-usual scenario, by 2050, projected deforestation trends will eliminate $40 \%$ of the current 540 million ha of Amazon forest (Nabuurs, 2007). Global deforestation rates are responsible for estimated 20-25\% of human induced GHG and are therefore a considerable part of human induced causes of climatic instability. The Reduction of Emission form Deforestation and Forest Degradation (REDD) is considered under international climate change negotiations to be a feasible mitigation option due to comparatively low-cost scenarios. This will inevitably require a strong resource flow from rich and wealthy entities towards the Coalition of the Rainforest Nations (CRN), the poor countries that hold the remaining rainforest habitats, to offer these countries the needed technical and financial support. Under international negotiations it was decided to establish a facilitating body to host these new development iniciatives under the World Bank Group. The Bank has set up the Forest Carbon Partnership Facility (FCPF) that will 
coordinate and control the financial resource flows to the rainforested mations under newly established funding mechanisms that reward countries for their national or regional implementation of Emission Reduction Programs (ER).

Bolivia has over time complied and cooperated with the requirements, regulations and incentives under the UNFCCC and the Kyoto Protocol. The country has complied with the commencing requirements under the FCPF and is in the process to further assess its capacities and needs for further implementation of the FCPF mechanisms. Further Bolivia has developed several climate change mitigation and adaptation strategies and has implemented a range of projects in the past. Through the implementation of a variety of conservation and combined Integrated Conservation and Development Projects (ICDP) Bolivia gathered a range of experiences in the field of forest protection and sustainable community development incentives. With the in 1997 established Noel Kempff Climate Action Project, Bolivia is host of the first great-scale REDD project in the world. Like the Noel Kempff project, great-scale implementation of REDD programs will require extesive and sustainable capacities to combine the need to conserve forest ecosystem biodiversity, monitor the accounted emission reduction, establish the needed local participation and supply the needed support for local communities to establish economic alternatives (Asquith, 2001).

The proposed developments towards further large-scale implementation of REDD in Bolivia are set in a country of great instability and political, social and cultural oppositions. The planning and the design of these new REDD development schemes are highly depended on political will, and the participation of local and indigenous people in the design of their future. It is their future that is discussed on international and national scale but has yet to reach the ground in a respectful manner (Tauli-Corpuz, 2007). Bolivia is the poorest country of South America and the majority of Bolivians suffer under post-colonial inequality, comforting the leaders of the country's economic elite. With a history of pro-rich exploitation Bolivia offers great opportunity for change towards the creation of sustainable pro-poor development and conservation projects (Grieg-Gran, 2005; Kaimowitz, 2007). But due to inequality in the country's multicultural societies, exploitation and lack of common vision remains strong in Bolivia as it does on international scale 
through unequal and injust governace of climate change negotiations (Timmons Roberts, 2007).

This research aims to highlight all significant challenges in the development of REDD strategies in Bolivia and assess these from an attempted earthcentric perspective. Due to the scope of this research it will not supply in-depth examination of the wide range of strategic concepts that challenge the developments of REDD that span: developing sustainable local income solutions; over-strengthening national institutions to implement these developments from a national perspective; and international negotiations that define what and how REDD development support will reach the ground in CRNs. However this research will supply, based on the given overview on the topic, in-depth vision of the pressing ethical issues of injustice and participation that need to be addressed in the design, planning and further implementation of any REDD developments on all levels. 


\subsection{Research Aim}

To explore the development of REDD mechanisms in Bolivia with the intention to evaluate them in the context of local and global climate injustice for further consideration in the development process of REDD strategies.

\subsection{Research Objectives}

- To examine the development of REDD strategies in the negotiations on national and international scales.

- To explore Bolivia's current socio-political, economic and cultural issues and to describe the current setting for the establishment of REDD strategies.

- To assess the work of the National Climate Change Programme and other collaborating parties on the development of capacity studies and pilot programme plans.

- To assess the development of the Global Forest Carbon Facility and their established mechanisms

- To identify and define the main encountered problems in the development of Bolivian REDD incentives in capacity assessments and pilot project planning.

- To reflect on these challenges, and define recommendations for the future development of REDD strategies on a local and global level.

- To strengthen the call for fair, sustainable and true commitment from the historically most emitting countries for global CCM and to extend the discourse on climate justice. 


\subsection{The Structure of this Research}

After examining methodologies, methods and the perception that formed this research, this study is structured to first give a general understanding of the topic from an international perspective. It then aims to describe the setting of the researched development concept by focusing on Bolivia's current issues. The structure aims then to narrow the focus to the national level by looking at climate change strategies and national REDD application processes. The definition of the challenges in these developments of REDD strategies will bring the reader to the climax of this thesis. In the conclusion regarding REDD development incentives, the focus is widened again to reflect the locally examined issues within a broader international context.

\subsubsection{Chapter Two}

In this chapter my personal position and perception will be explained and the underlying epistemology of this research will be explored. The change of focus from the original aim to explore the possibilities of a specific REDD mechanism proposal in Bolivia to a exploratory study of the current issues in the planning, design and preparation for implementation of World Bank funded mechanisms in Bolivia are examined. Clarification is given on why Bolivia was chosen as the target region. Further the underlying research methodology and methods are explained. The choice of participants and the interaction with these are explained. The ethical considerations that played a role in this research are examined and the problems encountered that led to the partial fulfilment of the research aims of this thesis will be elaborated upon.

\subsubsection{Chapter Three}

Chapter three aims to offer the required background information on the REDD concept and how this has developed over the recent years. The history of the needs for doing so and the current state and rates of deforestation as a major emission source are assessed and defined. This will lead to an evaluation of current and past developments in 
the international CCM efforts to find urgent solutions to achieve REDD on a great scale. The costs of REDD are examined and the valuation of forest is discussed. This leads to a gathering of expressions of different perceptions on the issue and an assessment of the role of local participation in the international discourse. This will lead to the presentation of the FCPF as most important funding source for current REDD and current efforts in Bolivia. 


\subsubsection{Chapter Four}

Chapter Four aims to build an understanding of the current issues in Bolivia that form the setting of my research by assessing the country's geographical setting, current political history and economic development. The political situation in the conflict about Bolivias new socialist constitution is explained and the indigenous struggle against exploitation and oppression of the economic elite is elaborated on. It is attempted to offer the background knowledge to understand the challenge that researchers, conservation, and development planners face in their implementation of REDD programs and projects. However, by doing so and by describing the floods witnessed in January 2008, this chapter attempts also to display the harsh reality local and indigenous people face on the ground and to give an expression of how inequality, injustice and exploitation have formed the current unstable situation in the country.

\subsubsection{Chapter Five}

This chapter narrows down the focus again by supplying the reader with an introduction to Bolivias climate change strategies and related negotiations. More specifically it will focus on the current developments under new REDD funding mechanisms and Bolivia's work to comply with their guidelines. The analysing, planning, and consulting processes under the currently developed mechanisms are examined and discussed. This aims to give the reader overview of the current state of the development of REDD incentives in Bolivia and offers an overview on future plans for the conceptualisation and implementation of these.

\subsubsection{Chapter Six}

The sixth chapter aims to define the climax of this research by broadening the understanding of the challenges in the above-mentioned conceptualisation and implementation of REDD incentives in Bolivia. Reflecting on the supplied background knowledge in the former chapters this chapter aims to define and outline the most important issues and 
problems in the development of REDD in an unequal, unjust and unstable environment like Bolivia. By this it aims to offer the reader an overview on these pressing issues. These will than be used to define focus areas and further research aims that might contribute to future REDD development efforts.

\subsubsection{Chapter Seven}

The concluding chapter will reflect on the explored knowledge on the developments of REDD in Bolivia and will aim to give positive and progressive reasoning for the evaluated and needed steps forward. Even though the identified challenges are not examined to depth they will be outlined and assembled in a exploratory fashion to allow the reader to built an overview over the needed proceedings in future local and global REDD efforts. These will thereby form a demonstration of what important issues will be faced in further REDD incentives in Bolivia, as in other CRNs, and what issues of inequality and injustice will need to be addressed to assure the sustainability and integrity of future REDD developments.

\subsection{Conclusion}

When I started the research for this thesis I was primarily focusing on the establishment of REDD mechanisms by observing the international discourse about it. This was challenging due to the contemporary nature of the research topic. Though defined, the research aim kept on evolving with the development of my knowledge about the REDD discourse. In Bolivia the apparent developments required again to change aim and objectives due to the information I gathered on current developments of REDD strategies in the country. However due to the wide-angle view, the research objectives formed a structure that examines the international, explores the national, focuses on the local, and draws on all to bring the gathered knowledge back into the broadened development discourse about justice and equity in current CCM efforts. 


\section{Research Methods and Considerations}

\subsection{Introduction}

This chapter explores how my personal perception shaped the underlying reasoning of my research and what methods were used to explore the development issues I choose to work on in this thesis research paper. The subsection on positionality will explain my desires and preconceptions and an exploration of the underlying epistemology will supply the reader with an idea of the researcher's intention behind this research venture. The methodologies and methods used are explained and discussed. This will lead to an assessment of the climate change mitigation approach that ignited my interests for REDD and how the realities in Bolivia effected my change of research focus. Further the various research methods will be examined and evaluated. The participants of my research will be presented and my collaboration with my interviewees will be explored. Ethical issues and my way of handling them are explored. This will lead me to the explain the failure to gather local visions and perspectives and how this became a vital loss to my research.

\subsection{Positionality}

My perception originated from a long, active, and passionate involvement in campaigns for fair, integral, and sustainable interactions within human society and especially human interactions with 'nature'. Influenced by ideas of reducing the personal impacts on the environment and on others in a globalising society I feel strongly for a permaculture, an integral interaction of life that seeks to provide a sustainable and secure place for life on Earth (Smith, 2004, p. 13). I view humanity as part of a greater system touching with nonanthropocentric perceptions of philosophers like Næss (1973, p. 3) who argued for a transformation to a 'deep-ecological' valuation of 'biospheric egalitarianism' (Brennan, 2008). This aims for a earthcentric or biocentric valuation of life that is independent of the usefulness of the nonhuman life to human purposes (Devall, 2001, p. 23). This approach further aims for a 
integral human understanding of its role in the Earth's biosphere and its interdependent systems as referred to in 'The Earth System' and 'Gaia a way of Knowing' (Kump, 2004, p. 15; Thompson, 1987) .

Over time, observing geopolitics, witnessing global injustice and researching environmental exploitation I developed a strong passionate viewpoint for the change to fair and respectful human interactions and an ecological sustainable, precautionary and respectable interaction with the biospheric systems our evolution depends on (Westra, 1995). The industrial excess and its induced changes of the earth systems through resource exploitation and the interference of climatic stability need to change course, away from its driving egocentric values, to supply a sustainable and prosperus future to the future's youth. These and the subtle ruthlessness of post-colonial exploitation in developing countries, in many cases purposely kept in a developing and post-colonial dependent relation to industrialised countries (Browne, 2006), leave me to partially include my critical views in this examination of REDD and international efforts to mitigate climatic instability. Because of my passion for an earthcentric perception of life and the perception that geopolitical developments are not acting upon the needed changes in the needed pace, I feel the strong need to use this academic venture to partially express my activist's passion for these issues in the academic debate on the development of REDD.

\subsection{Epistemology}

Development has been referred to by Robert Chambers as the objective to create 'good change' (Chambers, 2005; Overton, 2007). For the creation of good change the construction of critical analysis is vital to detect the areas of need and urgency in global issues of human and human-nature interactions. Therefore it needs to question the apparent systems of human leadership of current developments for their underlying causes and intentions to evaluate their role in evolving problems and to define needed changes for sustainable, equitable, and just solutions.

I will adopt the realist view that this research observed the development of REDD strategies as part of a real, ever, evolving world that consists of global interactions within the 
earthsystem and the "sets of international relations that have characteristic ways of acting" (Johnston, 2000, p. 673). These interdependent systems of ecosystem interactions on the physical earth's surface are therefore able to be identified and humanity's role within this system can be understood with the needed scientific observation, respect and non-anthropocentric vision. Yet a common deep ecological vision of human nature as one part of the of earth systems has failed (Kump, 2004; Næss, 1973). The networks and power structures in human interaction are identifiable under a realist approach, and are therefore responsible and liable for what action they take to lead development of humanity on earth.

From my view development knowledge is, due to the evolutionary nature of the subject, a construct of post-structuralist observations of current events and developments that do not produce a static image but an evolving concept. Development observation becomes then identifiable as theoretical knowledge when contested by a diversity of other academic devevelopment observation. However from my perspective for an integral development discourse non-academic observations should be valued equally.

This research attempts to use the observed developments of REDD concepts in a post-positivist fashion to allow the involvement of my personal perception in the argument of my thesis topic (Mansvelt, 2005, p. 253). My personal approach to the research topic is one of critical realism based on a perceived feeling of the need for passionate and strong reasoning in the current academic discourse. The research topic is set in an atmosphere of urgency in a global situation of climate change scenarios that are challenging the future of our offspring and the future generations. It is the academic discourse that shapes the knowledge that built the base for development concepts. It is therefore my choice to take this opportunity to strongly argue in a time where enough talk is done but urgent action, commitments and justice is needed.

\subsection{A Direct Barter Ideology}

During the definition of my research topic I was highly inspiring a proposal for REDD stategies proposed by one of my lecturers due to its underlying values. The 'Direct Barter Exchange' concept was developed by Dr. Sean Weaver as a trade- 
off mechanism between the community of the West coast of Aotearoa's/New Zealand's South Island and the Aotearoa/New Zealand government. The environmental community in Aotearoa/NZ had pressed to stop native logging on the West Coast but economic leverage was needed to give the local community reason to end old-growth forest logging. Weaver's attempt was to create a development wish list, a direct barter portfolio, of the local community by consulting the locals to find their wants and needs (Weaver, 2007). This was presented to, and agreed upon, by the Government and the local community agreed after negotiations to end native forest logging for the establishment of local trustfunds, holding \$NZ135 million for local development initiatives.

The main issue of this concept that gained my attention was the fact of fair-trading, direct barter in fair negotiations, where both entities worked together to make the desired possible. And this is what I would like to see in international CCM and CCA efforts too, except that industrialised, the powerful entities of geo-politics do not have a good reputation for fair-trading and unconditional exchange of efforts and goods. This I see reflected partially in the way negotiations have been attempted by some of these industrialised entities in REDD negotiations. And this is the reason why I wanted to see what development wish lists could look like in Bolivia and how their trade could be approached. Weaver's attempt and desire to find fair and workable solutions for using this great opportunity for international exchange under REDD inspired me to contribute to the aim of climate justice in current REDD efforts.

\subsection{Why Bolivia?}

I chose Bolivia for several reasons. From a historical and cultural perspective I was highly attracted by Bolivian history of cultural diversity exploitation and indigenous struggles. Bolivia, the poorest country of South America, its current socio-political and cultural and indigenous struggles represented a difficult and challenging place for research on REDD developments. Bolivian experience in forest conservation linked to alternative approaches like payments for environmental services and indigenous empowered projects offered interesting case studies too. Further its amazing expanse of forest has in the past not been approached by big scale deforestation as in neighbouring Brazil but in the past years this has picked up in 
destructive pace. Due to its forest resources and deforestation conditions it is part of the Coalition of Rainforest Nations and has through its history of UNFCCC negotiations pressed for fair and urgent establishments of REDD incentives and funding mechanisms. These amongst other points focused my interests and my research on REDD development issues in Bolivia.

\subsection{Change of Focus}

This research started out of a personal attraction to the ideology of 'direct barter' based mechanisms for future climate change mitigation (CCM) strategies that focus on REDD. At the start the aim of this thesis was therefore to explore the ideas and visions of a different country, other than the Vanuatu Carbon Finance Project (Vanuatu, 2007), or a different forest inhabiting community on the direct barter approach. The research objectives were set to explore the context of a possible development wish list of a different entity like Bolivia or an entity within its borders. I wanted to gather different local opinions on the development of REDD strategies on a international scale and find out what the achievement of REDD was worth to the people on the ground.

However, due to a lack of prior communication and poor Spanish skills it was difficult to gather sufficient knowledge about the development focus of REDD mechanisms in Bolivia from Aotearoa/NZ. In Bolivia it became apparent that the main governmental focus was to work on a capacity analysis for further applications for the funds of the Forest Carbon Partnership Facility (FCPF). This was done in collaboration with several big NGOs, and several economic and scientific consultants. The focus of work in Bolivia shifted my research interest from focusing on the possibilities of one certain type of mechanism to investigate the complexity of the already favoured and applied REDD development incentives in Bolivia. It became interesting how different actors emphasise different issues and how the FCPF mechanisms secured the overall participation and agreement of all stakeholders. The new aims and objectives were asking for the main problems and challenges in the implementation of the FCPF mechanisms. Additionally I wanted to ask for personal visions and critiques of people who were working on the creation of REDD in Bolivia. Even though a slight shift of focus it mend to evaluate the implementation of 
a set concept, design by the $F C P F$, rather than asking for the possibilities to establish local incentives and initiatives. The focus lost the notion of actively promoting the idea of fair and equitable mechanisms by exploring for a direct barter portfolio.

\subsection{Methodology}

Due to the complexity and diversity of my research aims I had to approach my research methodologies from various angles. My methodological approach consists of qualitative research that was to be extended by participatory methods but failed to do so because local forest inhabitant participants could not be contacted for participation (Mayoux, 2006, p. 117). Qualitative research was used for the assessment of current literature on the topic and for the examination of international negotiations and correspondence on REDD. Also for the analysis of Bolivia's current situation, the evaluation of other conservation projects and for the gathering of opinions on the most apparent problems in the achievement of REDD in Bolivia, qualitative research methods were most appropriate. Active qualitative research methods consisted of consultation of key informants through formal and informal semi-structured interviews. All empirical data was gathered from secondary sources and a number of individuals were kind enough to supply me with the needed scientific, land-use-change and deforestation information. However I learned from my methodological approach that a wider, and deeper participatory approach to my research would have been highly profitable for my research outcome and for my personal satisfaction about the interactions with my participants. This could have been internships or collaboration with key institutions or organizations that would have allowed me stronger connection, and therefore stronger participation, to local, by REDD strategies affected, communities.

\subsection{Methods}

As indicated above a range of different methods were used to carry out this research project. These methods complemented each other in the evaluation of my gathered data. The primary research was undertaken by semi-structured interviews with several key informants from various backgrounds. Further I adapted to local people's livelihoods, their culture, their 
needs, I got to know my perception of Bolivia and connect to Bolivians through informal conversations. My primary research methods further aimed to empower participants by asking and researching for local visions and needs. However I could not reach the local forest inhabiting groups that would have been really empowered to have their voices included this research and therefore in the academic discourse on REDD. The secondary research was constituted of contextual literature reviews of contemporary journal articles, other publications ranging from climate change science to environmental ethics, reviewed international correspondence, conference papers on REDD and empirical data gathered on land-use change and deforestation in Bolivia.

\subsection{Participation of Interviewees}

Through literature reviews and internet searches for the organizations and key informants that were potential research participants, I developed an extended list of contacts before travelling to Bolivia. Due to the language barrier I could only contact all organizations in spanish three weeks before travelling to Bolivia. They were contacted formally by e-mail in Spanish and English and asked for a possible interview at the, for them, most suitable time and place. Further I contacted everybody again by phone or presented myself at his or her office or ministry. People I interviewed were: 


\begin{tabular}{|c|c|c|}
\hline Organisation & Interviewee & Role of Interviewee \\
\hline Vanuatu Carbon Credit Project & Sean Weaver & Project Leader \\
\hline Oficina de Desarrollo Limpio - PNCC & Gisela Ulloa V. & $\begin{array}{l}\text { Head of the Clean Development Office } \\
\text { under the National Climate Change } \\
\text { Programme }\end{array}$ \\
\hline Liga de Defensa del Medio Ambiente & Marco Octavio Ribera Arismendi & $\begin{array}{l}\text { National Coordinator of the Research and } \\
\text { Monitoring Programme }\end{array}$ \\
\hline Independent Researcher & Cecilia González Peredes & None \\
\hline $\begin{array}{l}\text { SERNAP, Servicio Nacional de Areas } \\
\text { Protegidas }\end{array}$ & Carlos De Vgarte Ochoa & $\begin{array}{l}\text { Head of the Geographic Information } \\
\text { System }\end{array}$ \\
\hline Requested Anonymity & Requested Anonymity & Leading Position in a Environmental NGO \\
\hline Conservation International & Clea Paz & Programmes Manager \\
\hline Conservation International & Stephan Halloy & $\begin{array}{l}\text { Director of the Science Unit for } \\
\text { Biodiversity, CBC ANDES }\end{array}$ \\
\hline $\begin{array}{l}\text { Ministerio de Desarrollo Rural, } \\
\text { Agropecuario y Medio Ambiente, } \\
\text { Dirección Forestal }\end{array}$ & Jaime Villanueva Cardozo & General Director \\
\hline Fundación Puma & Nuria Bernal Houerud & Programme Monitoring \\
\hline Superintendencia Forestal & Dr. Rolf Wachholtz & $\begin{array}{l}\text { Integrated Expert on Deforestation and } \\
\text { Forest-Fire Controling }\end{array}$ \\
\hline $\begin{array}{l}\text { FAN, Fundación Amigos de la } \\
\text { Naturaleza }\end{array}$ & Joerg Seifert-Granzin & Head of the Environmental Services Unit \\
\hline
\end{tabular}

My first interviews in Bolivia with Gisela Ulloa V. taught me the need to set a different focus in my following research due to her elaboration on Bolivia's current efforts to establish REDD incentives. However Ms. Ulloa V. invited me to a meeting of a committee that was working on a capacity study for the World Bank's FCPF (further described below) and this offered me a wide range of contacts. This was very helpful since researching without the needed language skills is very difficult. From then on I focused on talking about the apparent problems in large scale conservation projects and asked for personal visions on how large scale REDD projects could be made possible. In the following interviews this focus led to a gathering of a wide range of difficulties in the creation of REDD in Bolivia from different organisational and personal perspectives. I interviewed several representatives of local and international environmental NGOs, and government ministries. Additionally I tried to establish further contacts with university research units and indigenous rights groups. This was difficult though due to poor but improving spanish language abilities but 
organising and interviewing officials in spanish taught me a lot about the importance of communicational skills.

When I travelled into the lowlands around Santa cruz were I'd plan to gather further data from NGOs and the Forestry Superintendencia (Ministry of Sustainable Development and Planning), I failed to organise interviews with forest communities due to major floods created by heavy rains (the situation will be described further below). This made it not only impossible to access the REDD program's affected parts of the forested lowlands but also influenced my research focus due to the urban-based interview sources. It felt unacceptable to visit and research in forest communities where annual crops were wasted, people died and starvation and illnesses were on the rise.

\subsection{Semi-Structured Interviews}

For the organization of these interviews it was important to establish respectful communications with the interviewed informants. As mentioned above this was done predominantly through e-mail and phone contacts. The interviews itself were, if given consent from the participant, recorded on dictaphone. It was further communicated that the recording could be interrupted at any stage or that recorded information could be erased.

I approached my interviewees in a formal way but using an informal interview structure. Even though I was aiming to ask more or less the same questions the semi-structured approach offered me the freedom to follow issues that arose and further explore these topics from my initiating questions (Willis, 2006, p. 149). Besides questions about the experiences, work and plans of the addresses organization I additionally always attempted to gather personal visions of my interviewees. This turned out to be the, for me more valuable perceptions and impressions for my research because only than impassionate arguments that reflected personal perception of their work and visions came to show.

\subsection{Ethical Considerations}

Secondary research on qualitative and participatory methods, the process of gaining the approval of the Victoria University's 
Human Ethics Committee and personal impressions from experiences of development practitioners provided me with a good mental preparation for what ethical issues I was approaching with this research. For my interviews I prepared an 'information sheet', a 'consent form', a 'confidentiality agreement' and a 'confidentiality clause for translators and transcribers'. After a three-week Spanish course I gained basic skills and got these translated by a professional translator in Valparaiso, Chile. The information sheet explained the purpose of my research and described my personal and scientific intentions of my research aims. This was done before changing my focus so the spanish translation was focusing on the opportunities of the direct barter approach. However I communicated this to all participants, explained how this change took place and informed all about the new more broadened research focus of the developments of REDD in Bolivia.

Before all interviews the participants were given an information sheet and a consent form and were informed about the attached conditions of allowing me to use the by them provided data. Additionally they were asked for their verbal consent to have the interview recorded by dictaphone. This was agreed on by all participants. After choosing one of the three options on the 'consent form' on how to handle the by the participant provided information they signed it and supplied me with this agreement. I then chose the equivalent option on my 'confidentiality agreement', signed it too and handed it to them for an assurance on how their information was to be handled. From experience my signature on this form supplied the participant with extra confidence to talk to me without hesitation. After the interview all participants were asked if, and to what extent, they would like to receive the research results after completion of the thesis.

By understanding and respecting the ethical considerations needed to work with people in development research, I learned a lot on what power information can have and how careful these must be handled by a considerate and respectful researcher. Further by acting politely and by handling gathered information with greatest respect for potential effects of miss-use, I hope I complied with the ethical standards of using informed consent' in current state development research (Brydon, 2006, p. 26). I hope further that none of the used information in this 
thesis will have any negative impacts on my research participants what so ever.

Even though I did not use participatory methods due the national flood catastrophe elaborated below, I highly valued the learning process of preparing myself mentally for this challenge. Having said this, I felt confident to attempt research within local communities in Bolivia but did not feel comfortable about the position in society I inevitably filled by being a young, wealthy and white foreigner that could at his age afford to travel the world. The impressions of poverty, exploitation and misery of people in Bolivia often sparked considerations on the overall means and necessity of development practice and my research project.

\subsection{Encountered Problems}

The two main problems could be shortly described as 'missing communication skills' and a badly chosen time for doing my research. First the language barrier restricted my research to a great extent. For the choice of participants it restricted me strongly in who I could talk and how the interview took place. With some participants with little or no English knowledge it was hard to establish a coherent conversation logically due to my poor spanish skills. This taught me a lot on how to approach research in different languages. From a logistical perspective I did not have any troubles due to extensive travel experience but for establishing contacts with organizations and people it turned out to be more vital than previously thought.

The second problem was the time and the resulting situation. I decided to travel to Bolivia in the Bolivian 'winter' rainy season. On the Altiplano, the high country of the Andes, this means low temperatures and increased rainfall and in the lowland in the east it extends into major rainfalls that cause floods. Knowing this I still attempted to carry out my research at this time. May be I assumed it would make the logistical side of my research more exciting but I realised it was shortsighted and naive. This and many other things contributed to the steep learning curve I experienced in Bolivia.

The problem was that when I travelled towards the major town of the lowlands, Santa Cruz de la Sierra, I got into the biggest floods for years that demolished villages, devastated crops and 
washed away transport routes. This was a sad and moving experience to witness. People who had little were left with nothing but hunger, famine, and increasing spread of illnesses. The Government declared a national disaster status, called for international help and President Morales stressed that increasingly strong weather patterns are caused by increasing emissions due to failed action from industrialised countries. Being 'stuck' in Santa Cruz I held a few interviews and attempted to get in contact with the organizations that could have potentially helped me to visit local forest communities to gather their visions on deforestation. No institution or organization was able to help me with this due to the floods and devastation they caused. Due to witnessing vast devastation and misery I also felt very disconnected, not happy and certainly not confident with my researcher's position. I felt not confident to ask people who were starving, who had their crops destroyed and who had other things to worry about than to listen to the questions of some foreign researcher. I wondered about and reflected upon my aims and wished I had chosen a topic on reducing livestyle's ecological footprints back home, the really needed climate change strategy. The inequality in Santa Cruz and Bolivia only mirrored the international inequality and exploitation apparent for supplying the systematic preconditions for excessive industrialised lifestyles. After a week of trying to accept the failures to gather local visions I left Bolivia on one of the still capable transport routes and regretted not having done the research a few months later with better spanish skills. This left me with the problematic situation of gathering only a certain group of stakeholders in the development of REDD. I missed gathering the visions, perceptions, and truths of the forests inhabitants that I wanted to focus on. These are the people who are going to be affected by the major development efforts under current REDD strategies. However I'm left with what I gathered and I can only try to include these local perspectives through secondary research for a needed representation in this thesis. Above all the research challenges contributed to a highly honoured learning experience throughout my time in Bolivia.

\subsection{Conclusion}

Due to the coherency of my research subject, my personal affection for the wellbeing of Earth and pressing ecological and 
geopolitical equity issues, I approach this research from an earthcentric perspective that attempts to offer an evaluating critical exploration of the developments of REDD strategies in Bolivia. I do realise that for an un-biased examination of REDD developments in Bolivia my personal preconceptions were a hinderance.

Several aspects hindered me following the methodological approach that I attempted to use in Bolivia. And, as stated above, I would have liked to extend my interactions with my research participants and within stakeholder organizations in Bolivia. This would, if I could attempt it again, result in an extended time frame in which I would try to organise internships within institutions or organizations in my research spectrum and/ or extended time within by REDD strategies affected communities. This would have increased my deeper personal and scientific understanding of my research topic and would have supplied me with a much broader and locally grounded base of knowledge in such a contemporary field of research. 


\section{Climate Change Mitigation and Deforestation}

\subsection{Introduction}

This chapter gives an overview on the need to reduce emissions that originate from deforestation and forest degradation (REDD) and to evaluate the international development efforts that aim to do so. The development of REDD as a substantial climate change mitigation (CCM) option is examined from a development perspective. The terminology of REDD is explained and the focus on deforestation from a local perspective is examined. The historical discourse on REDD incentives is explained and the design of REDD mechanism is examined in UNFCCC negotiations. Different approaches to the creation of REDD concepts are explored, compared and discussed. The value of avoided deforestation, of the interference in highly complex and diverse social- and eco-systems will be critically examined. This leads to the exploration of visions and perspectives from local and indigenous perceptions in the REDD discourse. Contrary the Forest Carbon Partnership Facility (FCPF) under the World Bank as the main funding facility for REDD incentives will be critically assessed. This chapter offers different critiques and perceptions on the development of REDD and closes by comparing and discussing these in a critical approach.

\subsection{The Need to Reduce Deforestation}

The rates of deforestation and forest exploitation in developing countries have raised concerns in the environmentally conscious community for many years. Already in the Brundtland report our Common Future" it was stated that "unintended changes in the atmosphere, in soils, in waters, among plants and animals, in the relationship among all these and that burning of fossil fuels would release carbon dioxide into the atmosphere, and that this causes gradual global worming" (WCED, 1987, p. 24). But science was not certain.

The preventative principle for emissions reduction had not been suitable for the interests of big business. As in 1987, 20 years later, the UNFCCC conference in Bali last year called for "the 
urgent need to take further meaningful action to reduce emissions from deforestation and forest degradation in developing countries" (UNFCCC, 2008b, p. 8). So far meaningful action on changing industrialised consumer behaviour has not been achieved at the required scale. Economically-focused politics failed to put in place coherent import policies and trade regulations to reduce poverty and to enhance fairness in the global economic market. Industrialiesed countries' excess prevailed without precautionary vision and without care for natural resources.

Deforestation rates have been criticised in the past primarily for the excessive destruction of some of the most diverse ecosystems on the planet and for a long list of other environmental and social impacts. The push into the green frontier has led to the increase of destruction of local forest communities, has moved forest dwellers into the cities and therefore further into poverty. Through clear-felling and monocultural use of forest soils the earth loses its productivity,

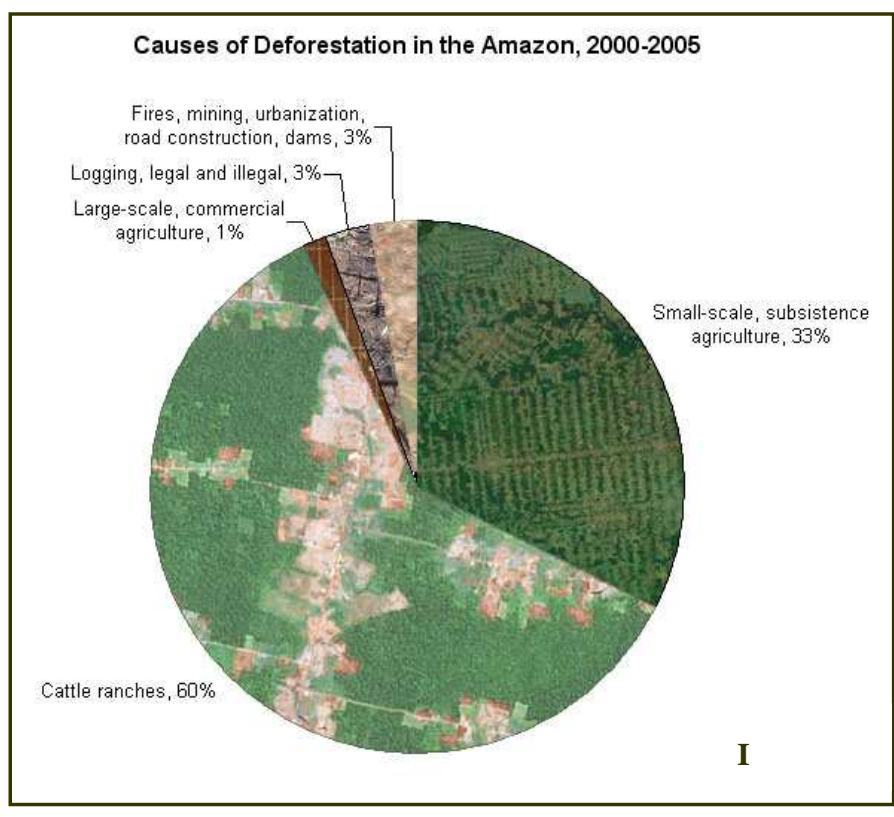

Causes of Deforestation in the Amazon 2000-2005: retrieved on the $6^{\text {th }}$ of May, 2008, from:

http://rainforests.mongabay.com/0812.htm erosion increases and opportunities for sustainable use of valuable forest resources are eliminated (Fearnside, 2005, p. 683). However the strongest driver for deforestation in the rain-forested nations is the conversion to agricultural lands or cattle ranching extensions. These direct causes are driven by many indirect factors like poverty, the security of livelihoods and the urge for economic growth of developing countries (WWI, 2006 , p. 102). The needs for rainforest products and agricultural production space of industrialised societies have been exported to the rain-forested nations like most environmentally destructive business these societies' wealth and comfort depends on. Without demand for cheap mass production of agricultural products there would be no need to supply these in 
the apparent excess. Therefore, the reasons for large-scale deforestation have predominantly roots in the excess of industrialised societies because it is industrial excess, our market signals, that require extensive expansion of resource production that lead to deforestation in rain-forested countries (Greenpeace, 2006; Nabuurs, 2007, p. 566).

In 'Earth Politics' it is pointed out that the countries that have emitted the most and gained the most wealth need to pay for their harm through the revaluation of the price of all products. Market prices, like the prices of meat ranched on deforested lands, have to tell the ecological truth of the production (Weizäcker, 1994). The ecological truth should include the costs to produce the certain product in a sustainable and ecological sound way that stops further over excess of resources and further destruction of vital ecosystems. But this, despite a growing production of sustainably produced forest products, has not yet happened to the required extent. Finding fair solutions for creating incentives that reduce deforestation without negative impacts on the country, local inhabitants and indigenous nations is a diverse and complex challenge due to the variety and difference of the causes and drivers of deforestation in rain-forested countries.

The international efforts to find mechanisms to reduce the deforestation rates around the planet have only gained momentum since the amount of GHG emissions from deforestation became more important to the international community to mitigate climate change. With the scientific evidence of the IPCC reports and a growing global awareness for humanity's climate changing impacts, this source of emissions became highly interesting due to its significant percentage of around $20 \%$ of human-caused emissions (Weaver, 2006, p. 245). Being a quarter of what we need to reduce it was thought to be a simple and of course economical attractive way of reducing anthropogenic GHG emissions. Further this could leverage the still growing emissions from developing countries that need to gain the right to develop too. Climate politics under the UNFCCC developed greater interest for this REDD climate change mitigation option in 2005. Since than the efforts have been significant, the willingness to pay for these has risen too. The need to reduce deforestation, the emissions from deforestation and the underlying need to finally create fair and sustainable development solutions to reduce poverty, hunger and injustice in 
developing countries and equity, peace and precautionary policies on international scale are more urgent than ever.

\subsection{Deforestation, Forest Degradation and GHG Emissions}

The global forest cover extends over about 30 percent of the land surface of the Earth, approximately 3,952,025 million ha of forest. Between 1990 and 2000 8,868 million and between 2000 and $2005,7.317$ million ha of these forests were lost annually, equivalent to an average of 20,000 ha per day (FAO, 2007, pp. 115, 64). South America lost $2.5 \%$ of its forest cover in the period from 2000 to 2005. Sathaye et al. estimate that deforestation will continue, especially in Africa and South America, by just under 600 million ha being lost by 2050 (Nabuurs, 2007, p. 552). Soares-Filo et al., though projected under a business-as-usual scenario, predict a net loss of Amazonian forest of $40 \%$ of the current 540 million ha by 2050 (as cited in the 2007 IPCC report, (Nabuurs, 2007, p. 552). This implies for the earth system's integrity an unacceptable loss of biodiversity and GHG emissions.

Europe's forest cover in comparison, that has been more or less stable for the last century, has extended over 661,000 ha over the period 2000-2005, compared to Brazil that lost 3,103,000 ha in this time period. Bolivia for example lost 270,000 ha of its diverse forest in this period (FAO, 2007, p. 114). And in 2004 Bolivia lost $45,411 \mathrm{~km}^{2}$ of its forest, roughly $9 \%$ of the national forest cover and including the conversion of savanna and bush habitats the land-cover change rates accounted to $17 \%$ of the historical land-cover change (Killeen, 2007, p. 1).

The Millennium Ecosystem Assessment scenarios predict a forest area gain of 60 to 230 million ha by 2050 in industrialised regions. In the developing world the forest area was estimated to decrease by 200 to 490 million ha (Nabuurs, 2007, p. 545). Japan is keeping 68.2 percent of its land-area forested whilst importing about 40-45 \% of its required wood products, apart from wood-fuel, which adds up to $22,285,000 \mathrm{~m}^{3}$ of imports in 2004 (FAO, 2007, p. 125). The consumer influence, and therefore their responsibility for production practices in a world market, is unavoidable. The problem of resource exploitation is exported by industrialised countries and imported is the cheaply produced end product. Saying this it must be acknowledged that 
the amount of sustainably harvested timber has increased rapidly over the last ten years.

The IPCC Report from 2001 stated that an estimated 60-87 GtC could be conserved or sequestered in global forests by the year 2050 (IPCC, 2001, p. 325). In 2006, Soares-Filo et al. even estimated that 62 GtC could be sequestered by avoided deforestation in the Amazon basin only until 2050 as argued in the 2007 IPCC Report (Nabuurs, 2007, p. 552). This implies the potential impact of REDD incentives for climate change mitigation and the reduction of anthropogenic emissions.

Further it is stated that 35\% of the GHG emissions in developing countries and 65\% of the emissions from the least developed counties originate from deforestation (FAO, 2007, p. 74). This implies the importance of REDD efforts for developing countries to contribute to international climate mitigation measures. It also reflects the growing opportunities for development measures that could evolve if sufficient funding is supplied for REDD. The 2007 IPCC report further states "that reducing and/or preventing deforestation is the mitigation option with the largest and most immediate carbon stock impact in the short term per hectare and per year globally as the release of carbon as emissions into the atmosphere is prevented" as cited on the UNFCCC web site (UNFCCC, 2008a). The scientific basis for the need to act urgently towards REDD appears to be clear.

\subsection{Definition of REDD}

I see the need to clarify the term RED(D). The term RED was first an acronym for 'Reducing Emissions from Deforestation in developing countries'. Later the second D became the added concept of Reduced Emissions from Forest Degradation. The difference between deforestation, which is used for forest clearing over 90\% of the biomass, and forest degradation, is quite significant. As mentioned in the definition below, deforestation is mainly driven by large-scale industrial land clearing for agriculture. Forest degradation accounts for all other change rates to forest biomass, $80 \%$ of which are estimated to be from small-scale fuel wood collection (as cited from FAO (2006) in (UNFCCC, 2008d, p. 31). The inclusion of degradation in national or local mechanisms might seem of secondary importance when efficiency is the major focus. It is, however, not a matter of importance but of priority. In the international 
terminology the term REDD prevails to assure the inclusion of this emission source.

- Deforestation - human-induced conversion of forest to non-forest land uses - is typically associated with large immediate reduction in forest carbon stock, trough land clearing.

- Forest Degradation - reduction in forest biomass through non-sustainable harvest or land-use practises - can also result in substantial reductions of forest carbon stock from selective logging, fire and other anthropogenic disturbances, and fuel-wood collection

The above definitions are copied from Asner et al. in the 2007 IPCC report (Nabuurs, 2007, p. 550). From an outside perspective it might seem complicated or even too accurate for deforestation data-sensing efforts to include forest degradation. From a local perspective in Bolivia it is not even possible to control big scale deforestation, such as through 5000 ha land-grabs, due to lack of institutional capacity. On a local level projects should generally prioritise 'reduction of emissions from deforestation' because deforestation is the cause that has more wide reaching consequences, effects and is easier to detect (Wachholtz, 2008b). What need is there to include forest degradation data if you cannot even control the biggest causes of deforestation? Strategies of course depend on the main local drivers of Landuse change and need to adapt therefore to the local reality. Forest degradation data and prevention measures should be included in any emissions reduction strategy in the forestry sector, but the priority should, lie in the initial prevention of big scale deforestation causes due to the accountability of industrial causes and drivers.

\subsection{The Establishment of REDD Strategies under the UNFCCC}

The UNFCCC was endorsed at the Earth Summit in 1992 in Rio de Janeiro. It was set up in 1994 and has been ratified since by 192 countries. The Kyoto Protocol was agreed upon in 1997 and entered into force in February 2005 (Bosten, 2008, pp. 67, 6). The avoidance of including 'avoided deforestation' as a major concept to reduce emissions human-induced emissions on a global level in the Kyoto Protocol had the effect of further untamed 
forest destruction in developing countries. Based on the FAO Forest Resources Assessment 2005 the average annual loss of forest cover is estimated by the to be 13 million ha, recognising that it is an underestimate (Grieg-Gran, 2006b; Weaver, 2006). However the issue was first approached by the UNFCCC as agenda item \# 6 in the $11^{\text {th }}$ Conference of Parties (FCPF) meeting in Montreal, Canada in 2005 through a submission from Costa Rica and Papua New Guinea. In this submission the two countries argued for the establishment of a 'Compensated Reduction' mechanism. As proposed earlier in the 'Brazilian proposal' in 1997 it was asked to be established mechanisms to enable developing countries to gain carbon credits for reducing their emissions from deforestation below baseline levels (Murdiyarso, 2005, p. 4).

'Reducing emissions from deforestation in developing countries: Approaches to stimulate action', now called the Montreal mandate, was discussed on international level by participating countries and accredited observers (ICFRE, 2007, p. 1). Encouraged by positive pilot projects like the Noel Kempff Mercado Project in Bolivia the $11^{\text {th }}$ Cop decided to establish a contact group, to invite parties for further submissions on the issue and asked the Subsidiary Body for Scientific and Technological Advice (from now on referred to as SBSTA) to organise workshops. The SBSTA was than asked to report on all gathered considerations and recommendations at the $27^{\text {th }}$ SBSTA session in December 2007 in Bali (Seifert-Granzin, 2008a; UNFCCC, 2005b, p. 18). This was achieved through the strong request of Costa Rica, Papua New Guinea, and various other Rainforest Nations like Bolivia. Their submission asked for the inclusion of 'reduction of deforestation' in further action under the UNFCCC. Further it stressed to use this objective to contribute to the promotion of environmental sustainability, the eradication of poverty, the improvement of health standards and to offer broad-based education (UNFCCC, 2005a, p. 10) This submission highlighted the importance of the topic for global climate change mitigation and its importance for national and local development measures. Further submissions put forward by several parties for the $24^{\text {th }}$ meeting of the SBSTA in Bonn, April 2006 led to an extending base of experiences. In this workshop however the focus was to gather scientific and socio-economic understanding on the role of deforestation in developing societies (UNFCCC, 2008a, C). Following a the $1^{\text {st }}$ SBSTA workshop in Rome in August-September 2006, the Issue was discussed 
further in the $25^{\text {th }}$ SBSTA meeting that was held together with the COP 12 in Nairobi in Nov. 2006.

At this stage I would like to highlight one submission that I found very important due its perspective. The 'Submission of Views' by the Coalition of Rainforest Nation in February 2007 aimed to demonstrate "unity of commitment and solidarity of vision" from nations in Africa, Asia, the Caribbean, Central America Oceania, and South America. They represented the collective visions of developing rain-forested countries in the international negotiations. Pressing the integration of preventative behaviour in climate change mitigation measures, the submission called for fair progress in the climate change regime. The CRN discussed technological and methodological issues in the further creation on REDD mechanisms and mentions the questionable role and involvement of the World Trade Organization in trade for environmental services. Further the development of the Forest Carbon Partnership Facility (FCFP, the work and development of the FCFP will be further examined below) under the World Bank is presented and the developing possibilities for the CRNs are commented upon (CRN, 2007). This was one of the submissions considered in the pre-consolidation for the next $2^{\text {nd }}$ SBSTA workshop in Cairns. Again discussion about policy approaches, methodological requirements, and experiences from positive incentives dominated the meeting. Several approaches and proposals to the implementation of REDD were made and presented. FCPF and other potential funding opportunities for enabling activities and pilot projects were discussed (UNFCCC, 2007a, p. 9). The diversity of approaches will be examined below. However the Cairns workshop affirmed the needed steps to commit to REDD and to promote the needed decisions in the next $13^{\text {th }}$ Conference of Parties (FCPF).

At the $13^{\text {th }} \mathrm{CP}$ on Bali, in Nov. 2007 a two year consolidation period on the conceptualisation of REDD incentives ended. However the decisions taken by the CP 13 in Bali were significant but predominantly focused on further technological and methodological steps to understand the diversity of challenges in implementations of strong REDD incentives. Being a valid focus the decision protocol, from my point of view, failed to stress for the commitment of funding from Industrialised countries on the needed level and did not transport the needed acceptance of their historical responsibility. As the Bali Action Plan puts it "Noting that sustainable reduction in 
emissions from deforestation and forest degradation in developing countries requires stable and predictable availability of resources" (UNFCCC, 2008b, p. 8). As in their latest post-Bali submission Columbia stresses for the needed funding capacities in a different way. After two years of talk " a financial mechanism that will power the future REDD mechanism is not only urgent but imperative for the negotiations on this agenda item to move forward" (UNFCCC, 2008d, p. 8). From the EU's view the priority for establishing of sound methodological approaches for REDD will lead to extended funding motivation (UNFCCC, 2008d, p. 51). The work on developing REDD incentives under UNFCCC continues with the FCPF in place to function as the facilitating body. However it must also be recognised that the 'Bali Action Plan' is "recognising the complexity of the problem, different national circumstances and the multiple drivers of deforestation and forest degradation. And "this statement acknowledges that whatever actions and financial mechanisms are adopted to avoid deforestation, to work in the long-term, they must take firm consideration of social issues" as stated by FERN (2008). The need to develop agreement on the next binding emission reduction targets under post-Kyoto frameworks is vital. Assuming that local policy changes and international negotiations will need 2-3 years to implement the needed action, the international community needs to ratify a post-Kyoto protocol at the end of next year. Some say that what is needed is US leadership due to their immense responsibility for climate change (Bosten, 2008, pp. 25, 12). Whatever action is agreed upon and whoever will take the lead, action needs to be faster than words for once, if we seriously want to reduce emissions at the needed level in the next 10-15 years.

\subsection{The Value of REDD Incentives}

The costs of reducing emissions play a major role in our marketled world of climate change politics. The cheaper, the better and reduction of emissions has been described as one of the 'cheapest' options available. However who sets the price and what does this price cover? 
Assuming that the global anthropogenic emissions from average annual deforestation and forest degradation levels of 13 million ha are to be reduced by $50 \%$. The combined deforestation and forest degradation area from the 8 main countries is roughly 6.2

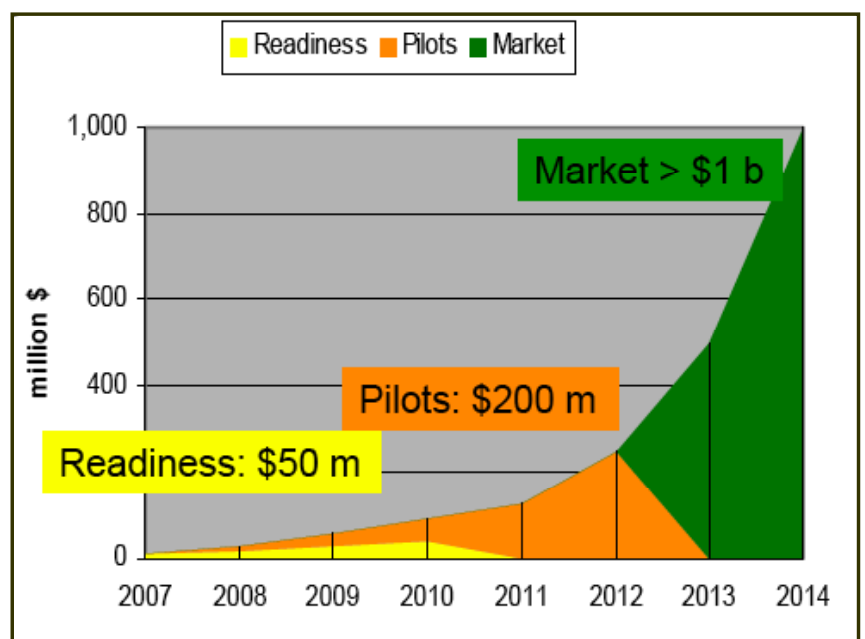

Funding for the different FCPF Mechanisms:

retrieved on the $6^{\text {th }}$ of May, 2008, from: http://unfccc.int/files/methods and science/lulucf/applica tion/pdf/070307noble.pdf million ha so approximately the 46 of the 50 \% reduction needed. This includes Brazil, Indonesia, Papua New Guinea, Congo and Cameroon and to a lesser extent Ghana, Bolivia and Malaysia. Grieg-Gran's national attempt was to estimate the complete elimination of these countries. The problem here is however to estimate the opportunity

costs and the returns made for the livelihood alternatives that need to be established to offer a substitutional incentive excluding deforestation and forest degradation (Grieg-Gran, $2006 \mathrm{~b}, \mathrm{p} . \mathrm{2})$. Therefore the economic opportunity costs for reduction of emissions from deforestation vary between 483 and 1050 US\$/ha (Nabuurs, 2007, p. 552). This accounts for the average need of a between 3 and 11 billion US\$/year. Grieg-Gran here states clearly how the price depends on the level of deforestation restrictions, level of alternative return payments and level of institutional implementation. An average is estimated to be 5 billion US\$ annually for achieving 50 REDD. (Grieg-Gran, 2006a, p. 9). As visible in the box above, the World Bank's Forest Carbon Partnership Facility (FCPF) has accounted \$US100 million for enabling developing countries to participate, \$US200 million to establish pilot plans and \$US1-2 billion until 2015 for the implementation of national strategies (Bosquet, 2007; Noble, 2007, p. 16). Assuming that the FCPF will be the broadest funding source for REDD, and supported by the G8 it most definitely will be, and acknowledging the estimates of SUS10-15 billion annually to achieve the wanted changes in the Coalition of Rainforest Nations, the green graph needs to keep on rising exponentially after 2014 to reach the needed funding. However, is the underlying philosophy of the World Bank's 
funding facility the one needed for action on World's forest destruction?

Costa Rica stresses for the 'polluter pays' principles that should be the base for any funding strategy for REDD (UNFCCC, 2008d). The Coalition of Rainforest Nations (CRN) affirmed that to really target REDD in their countries sufficient funding must be made available work towards an emission reduction of around $50 \%$ in this sector. These proposed a

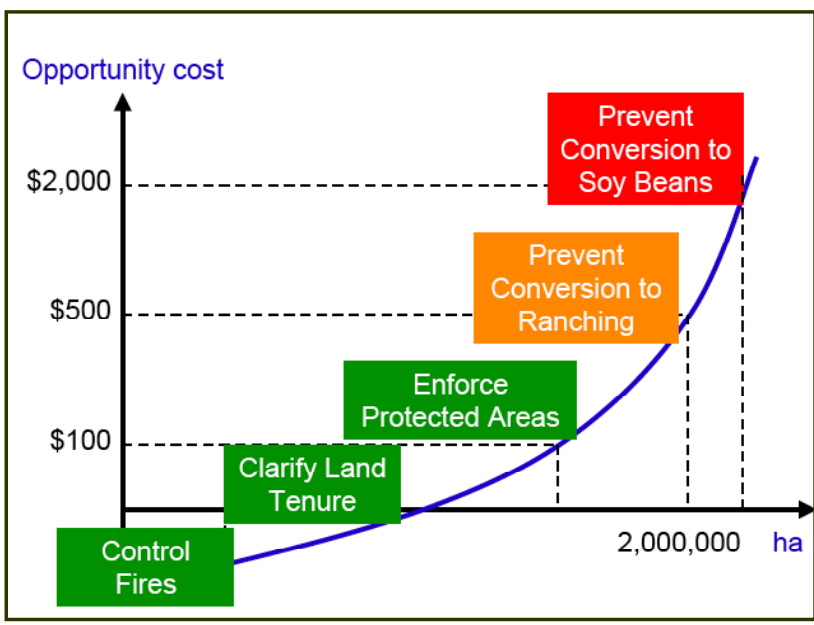

Rise of Estimated Opportunity Costs : retrieved on the $6^{\text {th }}$ of May, 2008, from:

http://unfccc.int/files/methods and science/lulucf/ application/pdf/070307noble.pdf

commitment of \$US10-15 billion annually to stimulate the wanted changes (UNFCCC, 2007b). Being a higher estimation from a developing nation's perspective it not only tries to represents the value of forest for its inhabitants but also the fact that the CRNs hold in their hand something valuable to exchange and it therefore should be their call to set the prize. All of the above mentioned countries are in fact highly exploited countries and these hold for the first time something valuable that is not and should not be easily exploited by industrialised countries interests. The value must be set by needs of the 1.2 billion people in local and indigenous communities that are dependent on forests for their livelihoods and their position must by all means not be exploited by the planners and brokers potential carbon market for REDD incentives. Crystal Davis mentioned in her critique of current REDD efforts that "the global carbon market is now valued at over \$30 billion worldwide" (2008). Gisela Ulloa V. replied to my questions about justice in global carbon markets: "We can see that only a few countries have benefited from it. Well, that's very good, but where has the rest of the money gone? The rest has gone to the brokers" (2008). Real improvement of people's livelihood to offer incentives to reduce deforestation is needed in Bolivia. The opportunity costs will not only have to exceed the income of local communities to a small extend but will have to offer consistent and coherent support to develop poor communities out 
of poverty. And these costs might also increase with growing income and development of livelihood condition (Ulloa V., 2008).

The main money of current international efforts, so it might seem from a developing countries perspective, flows into facilitation bureaucracy, expansive satellite-sensing scientist data and to boost credits trade business in the local industrialised economies. But for the start the valuation of forest-people's livelihoods and the care taking of forest ecosystems will have to be valued differently by neo-liberal decision makers for a global sustainable REDD efforts. This is bound into the crucial need to redefine our values of human existence in the earth's ecosystems. If the local entity is not satisfied with the payed 'Opportunity Cost', does not accept the provided value for their service it will not stop deforestation and forest degradation. The price is the acceptance of the alternative livelihood resource of the local entity. And this needs to be supplied by the historically excessive entities' respect and wealth. From my point of view only through this north-south movement, this redirection, this return of wealth and energy a sustainable reduction of deforestation will be possible. And it is this acceptance of the local people that should truly set the value of REDD.

\subsection{The Forest Carbon Partnership Facility}

The World Bank claims that it was approached by various developing and industrialised countries in 2006 to establish a facilitating institution for multilateral REDD exchanges. Following this, the World Bank proposed to establish this single multilateral institution to set up and facilitate the funding for REDD incentives developing for After the proposal was presented to the G8 in Heiligendamm, Germany in June 2007 the G8 agreed to support

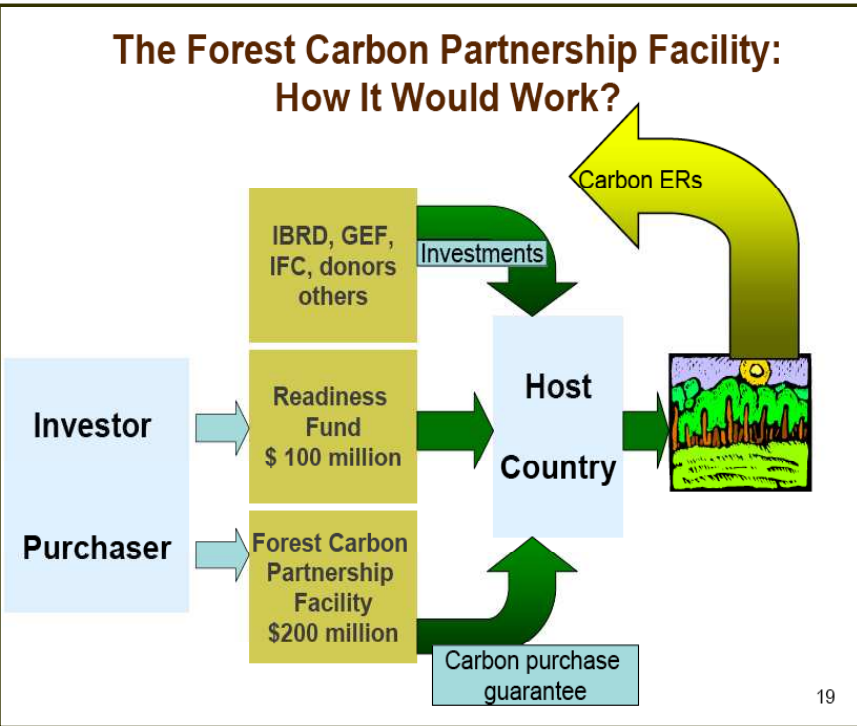

How the FCPF works: retrieved on the $6^{\text {th }}$ of May, 200833 from:

http://unfccc.int/files/methods and science/lulucf/app lication/pdf/070307noble.pdf 
establishment of this important climate mitigation-financing tool under the World Bank. The Forest Carbon Partnership Facility (FCPF) was founded in Feb. 2007 (Bolivia, 2007, p. 9) and officially launched at the $13^{\text {th }} \mathrm{CP}$ in Bali and its creation was welcomed by the European Union and others (UNFCCC, 2008d, p. 51). The FCPF than worked out estimated funding needs and established a programme of assessing the forested countries capacities for REDD.

I could not find evidence of a fair voting process under the UNFCCC to agree on the World Bank FCPF to handle and distribute up to 11 billion US\$ a year in development money that included especially forest people to the needed extent. It seems clear that the facilitation of the, for REDD needed, redirection of western accumulated wealth wants to be controlled and restricted by industrialised countries. It is unavoidable that the World Bank is a well-established funding institution with extensive experience in funding development projects and is therefore an understandable option for a rapidly needed funding institution. However development support has since the end of colonialism been used at times to influence other countries development for industrialised countries profits or interests. The body in the World Bank Group that will actually facilitate the and benefit of the current funding incentives will be the International Bank for Reconstruction and Development, one of the Bretton Woods institution that have been funding but also influencing postcolonial development since 1944 (Browne, 2006).

At the launching speech of the FCPF in Bali it was argued that "the challenge requires commitment to effective forest governance and ensuring that the conservators of forests - the forest communities - are rewarded for protecting their forest homes" (Zoellick, 2007). However several NGOs stressed long before Bali that the FCPF missed to include indigenous and local visions, rights and their valuation of the biodiversity that is at stake in the design of this highly important facility (Wilson, 2007). In their statement to the FCPF in Nov. 2007 Greenpeace emphasised their concern "that the Bank's "consultation" process on this important facility has been grossly inadequate" (Czebiniak, 2007). A Bank who has for decades participated in the funding of drivers of deforestation and therefore climate change (FPP, 2008, p. 1). The process of designing the FCPF under the World Bank, its internal structure, and its operational policies has not complied with various 
visions of indigenous nations, NGOs and the guiding principles of the nations of the rainforest coalition (Miles, 2007; TauliCorpuz, 2007; Wilson, 2007).

The UN Permanent Forum on Indigenous Issues (UNPFII) replied apprehensively on the launching of the FCPF in a sceptical manner. The Chair, Victoria Tauli-Corpuz, highlighted the fact that the World Bank is on one side proud to launch and host the FCPF as a growing funding body for REDD without in depth consultation of indigenous and local visions on REDD and the establishment of international funding mechanisms. Further she questions why, on the other side, the World Bank is the best place for such a vital funding facility due to their funding schemes that also finance fossil fuel extraction and industrial deforestation (Tauli-Corpuz, 2007; Wilson, 2007). Stressing that most governments or corporations still not respect indigenous sovereignty over their forest resources this should be acknowledged by all stakeholders of REDD funding and projects. Indigenous people should have a respected representation in the FCPF at the same level of governments, donors, and the private sector. Due to the feedback of many concerned parties the World Bank FCPF organised consultation meetings with local and indigenous representatives in February and March 2008. But it was expressed that these views will not be adequately included in the Institutional policies and practices (FPP, 2008, p. 3). Further concern is expressed about indigenous and local stakeholder rights to participate in decision-making in the FCPF. So far it is assumed that these will only be included on a invitation and no-voting-rights basis only (FPP, 2008, p. 5).

However the FCPF as described above has been establishing funding plans and regulations for the stages of their funding programmes and has gathered 'Readiness Mechanism' capacity studies from potential CRNs (this process is further described below). On of these is Bolivia that has worked on this capacity study. Once established the facility was of course approached from rain-forested nations due to the competition for funding access. Future will tell if the World Bank is going to be the right funding facility for REDD.

\subsection{Visions from the Forests}

In this subsection I want to examine the views on the reduction of deforestation from an indigenous, from a local perspective. 
For the achievement of REDD it has been argued consistently that the exclusion of local and indigenous knowledge and cooperation in the international discourse will lead to failure of plans to sustainably protect their forest homes. Further these have expressed that it is unacceptable that the value of forestecosystem are reduced to a market valuation of carbon per ha, set by the carbon market. It is against their views and philosophies to set a monetary price on their forest homelands (Griffiths, 2007, p. 17).

The attempted challenge, under the UNFCCC and the FCPF to establish and facilitate large-scale payment for Environmental Services (PES) schemes, needs to focus on the importance of local and indigenous stakeholder participation as recommended and examined by Wunder (2006; 2007), Kaimowitz and Sheil (2007, p. 568), Griffiths (2007, p. 15) Boyd et al. (2007) and others. In an assessment of forest conservation incentives in collaboration of conservation NGOs and two different indigenous communities in Bolivia, stearman argues that without a steady and in-depth consultation and participation in the management of future forest conservation (2006, p. 164). And as shown in the Noel Kempff Climate Action Project in the remote east of Bolivia, this has led to proactive involvement of local forest inhabitants. Further this shows that only with this proactive participation and design sustainable solutions will be found that do not restrict the local inhabitants in a negative way and ensures that the offered compensatory development incentives meet the needs and desires of these communities.

The indigenous people organization of the Amazon COICA expresses the need to change our interaction with forest ecosystems in an insightful way. "The current economic globalisation needs to change its market policies that impose cruel processes of environmental and human exploitation, whose consequences are the progressive inequity, violence, war and growing misery" (COICA, 2005, p. 11). These market policies must be a core target from coherent REDD efforts to sustainably tackle the problem. And so far these have not been targeted in the way it would be appropriate if $\operatorname{REDD}$ is needed to be achieved in the coming years. It is inevitable that the biggest drivers of deforestation are bulldozing and clear-cutting for industrial market signals, for industrial consumer behaviour. But so far of this side there is not much talk in the discourse (Greenpeace, 2006). The talk is focused on what the price is to cover the opportunity costs and to pay forest people enough to stop 
deforestation and forest degradation, how this funding can be made available and how it REDD projects can be implemented on a great scale. What about tariff and trade regulations of western countries that allow great scale resource production through deforestation? This is ignored to a great extent in the discourse. No doubt that establishing and strengthening forestry regulations in the CRNs will toughen business for industrial illegal deforestation but it is hard to see how this is going to work without the change in industrialised consumer behaviour. In biodiversity conservation it seems at times that the local and indigenous communities are part of research and promotion projects for great scale NGOs (COICA, 2005, p. 41). And this perception will be developed if effected local and indigenous people and communities are not included in the design of REDD strategies in a respected manner (Griffiths, 2007), for it is their future that is decided upon. From a conservationist viewpoint it might seem easy to pay local communities the opportunity costs to exclude deforestation and degradation but from a local perspective this might lead to a strong dependency on donor payments (Wunder, 2006). For the REDD challenge it must be achieved that the needs and demands from the ground reach the top of international design and planning groups. These development wish lists, these visions of future must be respected and fulfilled and from this 'top', fair and honest support must be given to achieve these local visions. This must be done to assure the sustainability of REDD from a local perspective. If defined as Payment for Environmental Services, Direct Barter Approaches or Compensated Conservation all that is thought of in the design and plans of REDD projects needs to respect local basic needs because for hundred of millions of people forests are primarily about supplying livelihoods and a home environment (Kaimowitz, 2007, p. 572; Pieck, 2006).

\subsection{Conclusion}

This chapter aimed to give a basic overview of the need for the reduction of deforestation, the establishment of REDD strategies under the UNFCCC and some of the numbers of deforestation data in the context of REDD efforts. Further it examined the valuation of forest ecosystems and their protection. It attempted to give a impression of the perceptions of the people who will be mostly effected by REDD incentives and who will not receive a high salary for their contribution but instead have a 
more or less imposed way of living. If this way, this development is good or bad will decide the sustainability of REDD. By approaching the issue from a critical viewpoint I hope to have approached and answered several important questions in the development of international REDD efforts. 


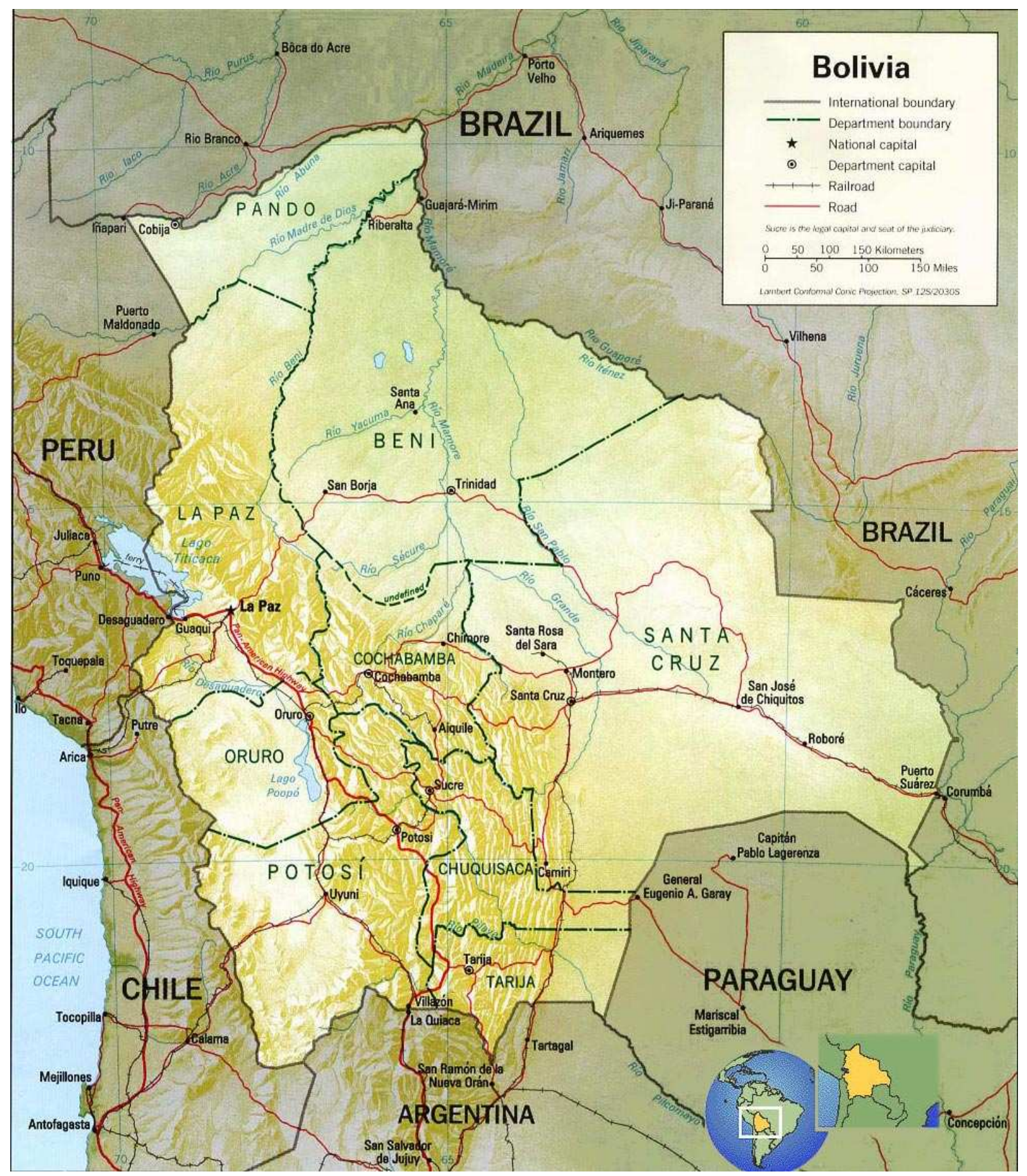

Map of Bolivia: received, $28^{\text {th }}$ of May 2008, from: http://www.geographicguide.net/america/pictures/boliviamap.jpg 


\section{Bolivia's Socio-Political and Environmental Situation}

\subsection{Introduction}

About two thirds of Bolivian people live below the poverty line, defined as less than 2 US\$ dollars a day. About 70 percent are of indigenous origin, rich in their cultural heritage, connected to their lands, and in a struggle to make a living (Bojanic, 2001 , p. 9). Bolivia is a country were exploitation has formed corruption from top to bottom within its own people. In this chapter I want to create an image of the heart of South America, the poorest country on the continent, Bolivia. I would like to provide the reader not only with the dry facts of a country but also communicate my personal impressions of these diverse lands and its people. The history of Bolivia is going to be assessed in consideration of its long history of indigenous cultures and centuries of exploitation of its resources. The historical background will lead me to an examination of the current struggles in the definition of Bolivia's identity under the first indigenous South American president, Evo Morales. The conflict about the new constitution that challenges old Bolivian economic power networks is highlighted and how Bolivia's role as the regions major gas supplier influences politics in santa Cruz.

\subsection{Bolivia's Geography}

Bolivia is the heart of South America. Geographically it is situated in the middle of the continent, landlocked by bordering Brazil, Peru, Chile, Argentina, and Paraguay. It ranges from an altitude of $90 \mathrm{~m}$ on the Rio Paraguay in the southeastern lowlands to $6,542 \mathrm{~m}$ on the Nevado Sajama, a Vulcan on the northeastern Altiplano, a high plane spreading across the Andes. The Eastern Lowlands and their connecting Andean foothills are mostly forested and, due to its climatic conditions, are home to the most biodiverse forest ecosystems on the planet. Due to the lower altitudes the lowlands and the Bolivian part of the Amazon Basin are humid climates and consists of tropical forest habitats similar to the climate of Brazil and Paraguay. The 
Andean foothills, incredibly rich in natural and resource diversity act as the linking eco-regions with the harsh conditions of the Altiplano. The rugged Andean environments constitutes of fast mountain ranges and the already by Inca cultures cultivated planes of the Altiplano. After Chile's occupation of Bolivia's western region that served as access to the Pacific Bolivia shares only the Largo Titicaca, as the highest elevated navigable lake at $3.805 \mathrm{~m}$ with Peru. However the Andean regions of Bolivia have incredible biodiversity, natural resources and consist of very special geographic features, one being biggest salt lake on the planet.

\subsection{Political Development}

The country was established after the independence fighter simon Bolivar came on his conquest through Peru to Bolivia that was the colonised by the spanish at the time. This led to the formation of an independent nation in 1825 with the name Bolivia to honour the quest of the independence fighter (Worldbank, 2008). Having been dominated and exploited by Spanish rule for many centuries, this led to many struggles to unite the different cultures and ethnicities that the new country, Bolivia, consisted of. With an indigenous population of $60 \%$ it went through more that 200 coups that fought against post-colonial power

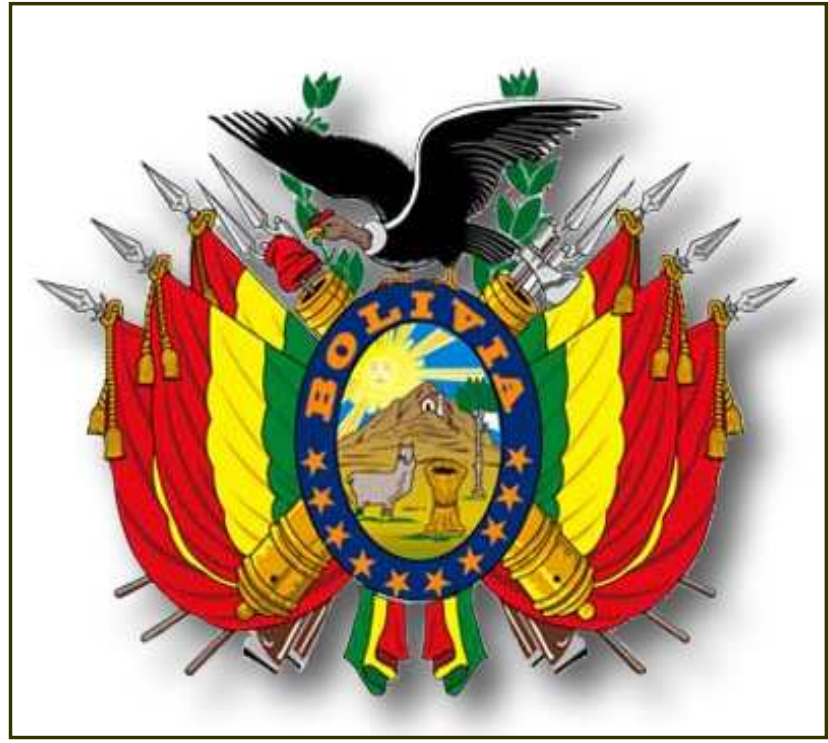

Escudo de Bolivial: retrieved $28^{\text {th }}$ of May, 2008, from: http://www.boembassy-

london.com/_bolivianembassy/images/default/Esc udo-de-Bolivia.gif

networks of the Spanish ancestral ruling classes. These kept power through influence or control over the main economic resource products and sold these for personal profits at a low price to foreign entities. And as accused, neo-liberal administrations had worked Bolivia to be the second most corrupt country on the planet, which weakened its institutional structures as stated by Transparency International (Prashad, 2006, p. 145). The strongest indigenous resistance formed 
between 2003 and 2005 to push for an end of the neo-liberal economic structures implemented by US allies Sánchez de Lozada, who governed in 1993-97 and 2002-03, and Hugo Banzer Suárez who ruled from 1997 to 2001. Their policies ignited the struggles of the 'water war' in 2000 and the 'gas war' in 2003 against the privatisation of important resources and raised the tone of conflicts against the govt-tolerate exploitation of this resource rich country. In the end of Lozada's presidency he send for helicopters to silence the demonstrations of the indigenous around La Paz, killing 67 and wounding hundreds. Despite this Bolivia as a "country where Latin America's most powerful social movements had risen up to resist and change destructive economic policies" was heading towards a socialist change (Dangl, 2007, p. 1).

This led to the presidency of Evo Morales, the first indigenous president of South America. He was honoured as the Liberator and declared as first indigenous president on the $22^{\text {nd }}$ of January in 2006. He called for an end of the colonial state and the amassing of capital in the hands of a few. Stressing that it is time to industrialise the national production to shift away from foreign-exploited primary resource production and to spend increasing profits for the well being of the Bolivian people. About his planned redistributing land-reforms against colonial large land-ownerships that would ask for unproductive land to be returned from private to state ownership, he said: "A cow is given 40 or 50 hectares to live. It is not possible that one has to be a cow to get 40 or 50 hectares." About the general distribution of assets from the economy and how these are used for enhancing education and health he said: "in Bolivia the neo-liberal economic model just does not work." Further he stated that he would serve "to deepen democracy, which is not only the right to vote, but also the right to live well" (Prashad, 2006, p. 57).

Coca is the holy leaf of the Andes and serves as medicine, ceremonial leaf and as needed diet supplement for the slavelike labour in the mines and conditions in other primary resource production on the high altitude of the Altiplano. Morales used to be a cocalero,

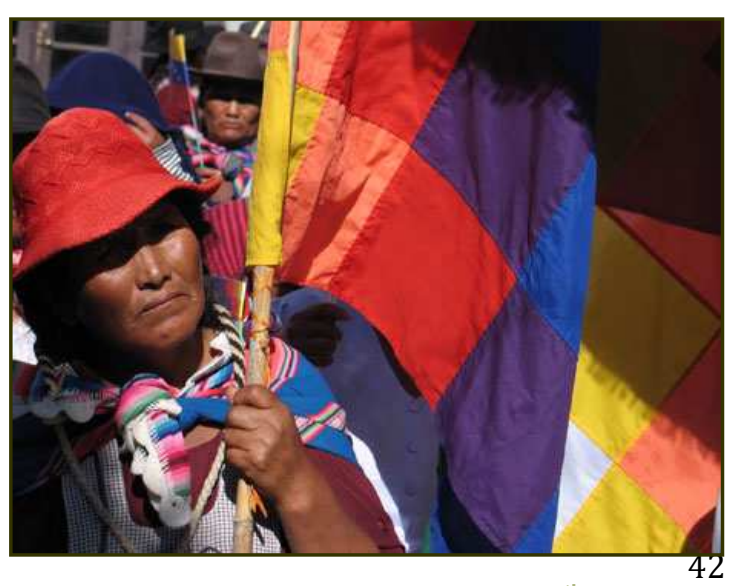

Indigenous Resistance: retrieved, $4^{\text {th }}$ of June, 2008, from: http://washingtonbureau.typepad.com/phot 
a coca farmer that had witnessed the effects of the US induced fight against coca production that was executed by former president as part of the US 'war on drugs'. This seemed however more like an excuse to spend an estimated \$US1.6 billion to strengthen armed forces in one of the resource richest country in the region and to defend the exploitive neo-liberal economic interests of the allied government administrations against indigenous socialist struggles and ideals (Prashad, 2006, p. 176). Exploitation and foreign interests have a long history in Bolivia. This history of colonialist and post-colonialist Spanish oligarchy and their enforced inequality in the country have formed a deep resistance and a deep apathy in seeing common goals and working towards common interests that are influenced by western ideals. This hampers the energy felt in the work to achieve REDD and influences the interests of different stakeholder groups (Wachholtz, 2008a). It is also the due to the exploitation in its past that poor Bolivians are mostly concerned with securing their livelihood. Morales is fighting for the interests of the poor, of the thousands of indigenous people that have been ignored by the ruling economic elite.

Bolivia is sitting on one of the biggest gas reserves in the region and these have been exploited by private sector entities for many years. The gas reserves of Bolivia have been supplying its neighbour countries with gas for decades and have become the most important gas supplier of economies like Brazil and Argentina. One of the first strategic moves of Morales was to nationalise some of these companies and their resource extraction contracts to share their revenues with the Bolivian people, to invest money in health, education, and social programmes. However this, imbedded in Morales 'new constitution', led to a rising resistance from power economic networks in the gas-rich lowland regions, especially Santa Cruz. The settled excess and the income of personal profit from exploitation of lower classes seemed to have been too comfortable to give up without a fight. With 100.000 people on the streets the department of Santa Cruz and other resource-rich lowland state departments voted for autonomy and against the new constitution that challenged colonial large land-ownerships and economic elites. Their campaign gained momentum and is at current state still fighting against the socialist reforms that are trying to tackle the incredible inequality in the country. The government has called the referendum for autonomy illegal that would try to secure the lives of the rich elite and that 
denies to share the resources in the 'sierra' with the largely indigenous population of the Andes. Since the beginning of the year these tensions have grown and people have died in the conflicts for and against a division of Bolivia. From the time I was researching until now the country remains in an extremely unstable position, politically, economically, and also racially (Caroll, 2008). This conflict is about the distribution of resources between indigenous and poor classes 'kollas' of the Andes and the white and rich elites, the 'campas' of the Sierra. A conflict for some as vital as to gain control over the only option to end poverty and misery and for the other to guard their elite's excess. The OAS, the Organization of American States, and the European Union have expressed their concern and hope that the next referendum that will challenge Morales and all department heads leadership on the $10^{\text {th }}$ of August will remain peaceful. This political instability has been and will be a difficult setting for the establishment of REDD incentives due to complete instability of the political atmosphere.

\subsection{Economic Perspectives}

In December 2005 the IMF approved a 100\% debt cancellation of an outstanding amount of \$US222 million (IMF, 2008). Also the World Bank agreed to cancel a total of 1.5 billion US\$ of Bolivia's debt in 2006 (Worldbank, 2008). However in 2006 Bolivia was still hampered by a total of 5.3 billion of external debt.

The estimated growth of the Gross National Product (GDP) between 1990 and 2002 was estimated to be 0.6\% as cited in Wards Latin American development summary (Ward, 2004, pp. 42, 43). In 2000 the estimated GDP growth rate reached $2.5 \%$. Morales came to power in 2005 and with the nationalisation of gas-industries and growing gas demand in the region the GDP growth nearly doubled to $4.0 \%$ in 2005, 4.6\% in 2006 (WorldBank, 2007) and dropped slightly due to higher inflation rates down to $4.0 \%$ as estimated by the CIA World Fact book. However due to increasing gasproduction, increasing gas demand by all surrounding countries and a higher govt revenue due to nationalisation of gas exporters the GDP is estimated to grow to a rate by 4.7\% in 2008 and by 5\% in 2009 (IMF, 2008). But compared the "growth in Bolivia has been very modest. In the last 50 years, the real income per capita in Bolivia fell in one percent point, while increasing in 350\% in Brazil, 200\% in Chile and 75\% in Argentina" (Worldbank, 2008). Bolivia is still the poorest 
country in South America despite its amazing resource wealth. Meaning that in 2005 Bolivia still had a GDP per capita of 1.001 US\$ compared to 4,386 US\$ in Argentina, 26.538 US\$ in Aotearoa/ NZ and the United States with 41.674 US\$. Has this country chosen to stay on the economic periphery as a primary resource supplier or has it been influenced to serve as such? However Bolivia's resource wealth, the gas industry and others, need to supply the needed income for Bolivia to establish better social, health and education systems and therefore become a better democracy and to work itself out of the economical periphery it exists in.

\subsection{Bolivian Forests}

About half of Bolivia is covered in tropical humid or sub-humid rainforests. In the lowlands the loss of about $2900 \mathrm{~km}^{2} /$ year in the epoch from 2001 to 2004 compared to $400 \mathrm{~km}^{2} /$ year in the 1960s. As mentioned in chapter 3 the total expansion of deforestation in the eastern Bolivian lowlands add up to 45.411 $\mathrm{km}^{2}$, 9\% of the original forest cover, until 2004. Adding the

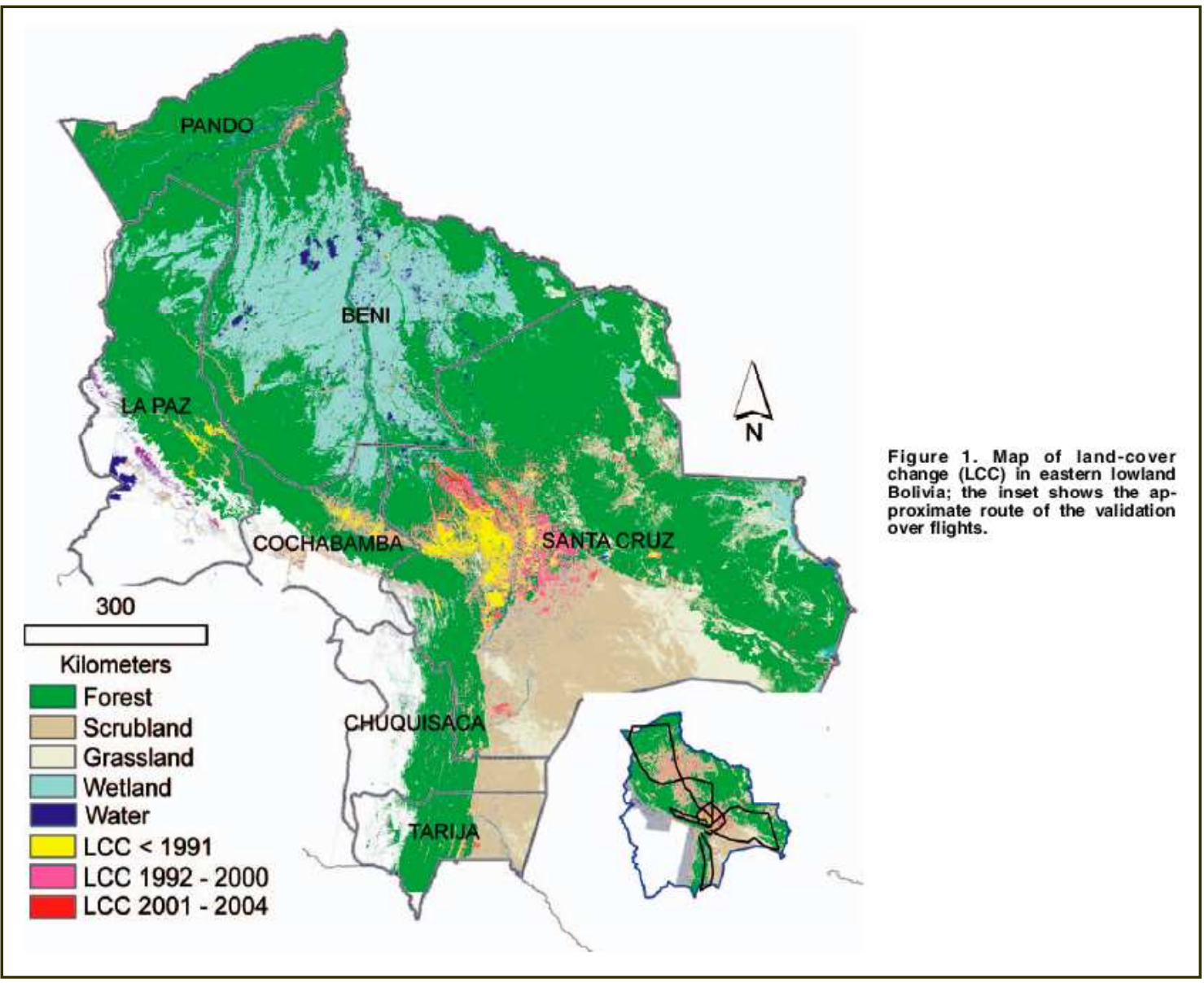

Land-Cover Change (LCC) in Bolivia: received from (Killeen, 2007) 
conversion of scrub and savannah habitats of $9042 \mathrm{~km}^{2}$ it represents $17 \%$ of total historical land cover change in Bolivia. After three decades of steadily increasing land-cover change the percentage of deforestation represents about 77\% of all types of today's land-cover change. Since 1990 Deforestation rates have tripled in 'forest management' zones and doubled in 'restricted use' zones that include protected areas (Killeen, 2007, pp. 1, 4). Even though protected areas have been successful in protecting biodiversity these are challenged by farmer's need to convert land to support their livelihoods (Paz, 2008; Ulloa V., 2008; Wachholtz, 2008a). However some protected are lightly populated and cover relatively remote regions and are therefore not under significant pressure of migrating farmers (Killeen, 2007). Three quarters of the lowlands are still covered by unbroken forest and savannah wilderness. And around 17\% of these lowlands are protected in protected areas (Killeen, 2007, pp. 1, $4)$.

As much as 2.2 million ha are announced by the Bolivian Govt to be sustainably managed and FSC (Forest Stewardship Council) certified as referred to in Killeen et al's examination that effectively contributes to a robust baseline assessment for future land-cover change monitoring. Based on the experience of the Noel Kempff Mercado Climate Action Project, a large-scale carbon sink project established in 1997, and various other forest protection incentives with different approaches, Bolivia holds a verity of experiences in sector of forest-protection and sustainable-forest-use.

In 1996 a new forestry law was ratified with the new aim to increase the sustainable management of forests. The law and the surrounding regulatory framework tried to solve and manage arising issues and conflicts between different forestry stakeholders. This and following developments of laws and regulations are until today primarily managed by the Superintendencia Forestal, an autonomous body under supervision of the Ministry of Sustainable Development and Planning. The Superintendencia regulates, controls and supervises all steps for the integration of sustainable forest use and management into conventional forestry practices (Bojanic, 2001, p. 12). With 160 staff it monitors 50 million ha of forests and has done so with increasing precision. This data is than available in the Internet to support the municipal institutions in control deforestation practices in their regions. However education, 
technical capacity is lacking and corruption is undermining the abilities of municipal institutions to effectively regulate and control deforestation, especially in remote regions of Bolivia. The Superintendencia Forestal is therefore organising trainings to build municipal capacities and offer support and advice (Wachholtz, 2008a).

\subsection{The Floods of January}

In last third quarter of last year scientists detected a beginning of the weather phenomenon 'el Niña' in the Pacific Ocean. This phenomenon, known as a reoccurring pattern caused by changing water temperatures in the Pacific, led to changing climatic conditions and heavy rainfalls in South America (WMO, 2008). In Bolivia this resulted in heavy rainfalls from the

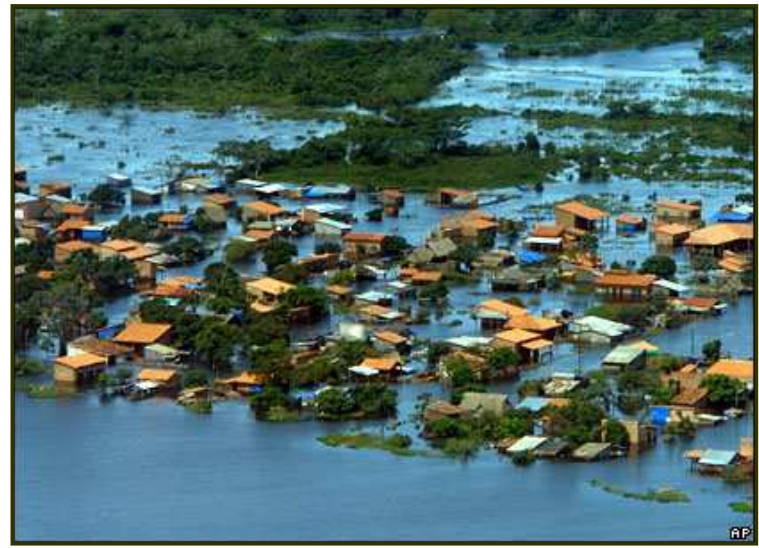

Floods: retrieved, $28^{\text {th }}$ of May, 2008, from: http://newsimg.bbc.co.uk/media/images/44416 000/jpg/_44416572_bolivia4_ap416.jpg beginning of January until March 2008. During this time Bolivia was exposed to dramatic floods mainly in the eastern sides of the Andes. However the whole country was effected by the disaster.

By march the $3^{\text {rd }} 78,988$ families were affected and 63 people died (OCHA, 2008b). Transport routes were destroyed; crops were drowned and damaged by hailstorms in higher altitudes. I witnessed major transport routes turned into muddy waterfalls, villages that were completely flooded, and people who tried to cook on little platforms in the roofs of their buildings. Others were forces away from their villages to seek shelter in temporary camps due to the heavy floods. In major cities the sanitation was problematic however the problems in these urban areas were improving by March. Further the health situation was endangered due to malnutrition, difficult access to clean drinking water and the spread of illnesses like Dengue Fever which was already regionally problematic like shown in graph I (OCHA, 2008a). 
The national response by Jannuary $23^{\text {rd }}$ was set national red alert level, to distribute 200 tons of food for the flood victims to

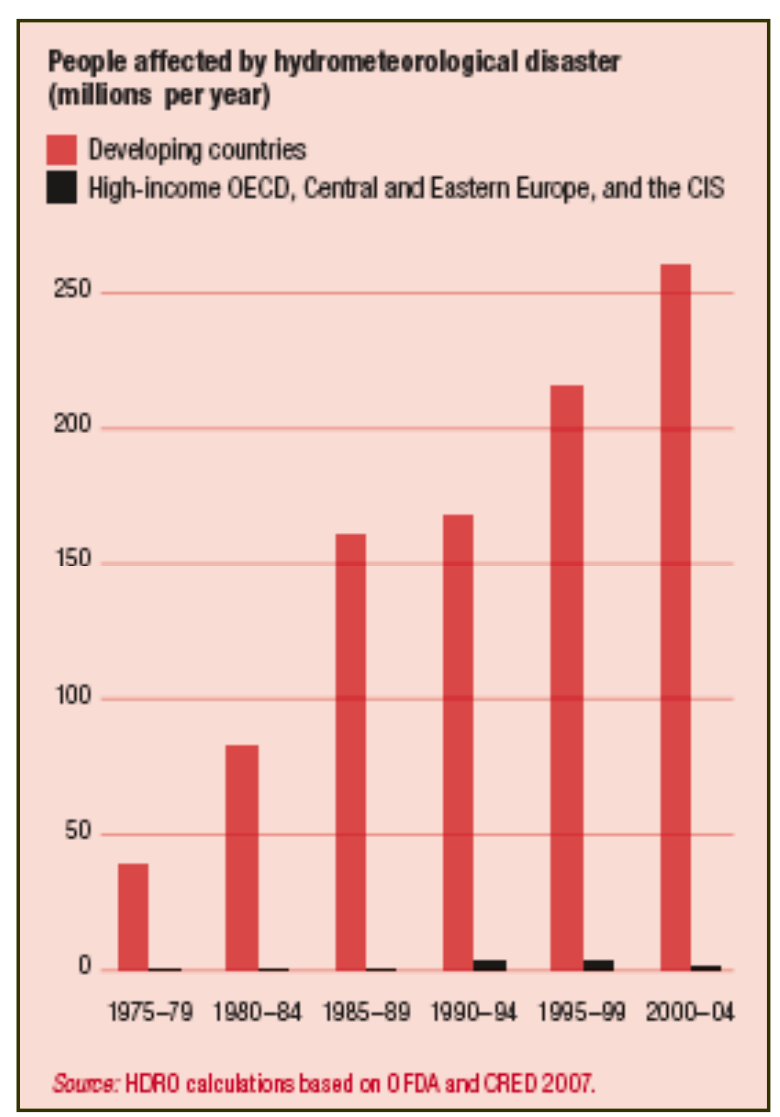

Climate Disasters are affecting more people: received from (UNDP, 2007, p. 75) supply materials like

blankets and spades. By the $7^{\text {th }}$ of March the international help gathered up several million to assist the flood victims and around 80 Megatons were distributed. This was done also by helicopter and boat to remote regions of the eastern lowlands (OCHA, 2008b). Even though help was provided the impact of such disasters on poor people's livelihoods and the misery that they cause is underestimated. For the rich elite the disaster was primarily of economic nature, crops were destroyed and revenues were decreased. For Bolivias poor it was a matter of survival that resulted in death or deeper misery for the following month. With this in mind it felt wrong to continue my research in poor forest regions in this setting. A poor country like Bolivia, and primarily its poor inhabitants will have increasing trouble to deal with big disasters like this if climate change will strengthen their occurrence. The global inequality in the adaptation possibilities for climate change impacts was mirrored clearly by the way it effected the different classes of Bolivian society. And even if this 'el Niña' phenomenon is not directly linkable to climate change, Morales' call to the industrialised countries to act upon their heritage of climate changing impacts and to reduce their emissions is a valid response. It is poor countries like Bolivia that are going to suffer first. And it is the poor in those countries that will bear the burden of western industrialisation first (Timmons Roberts, 2007). 


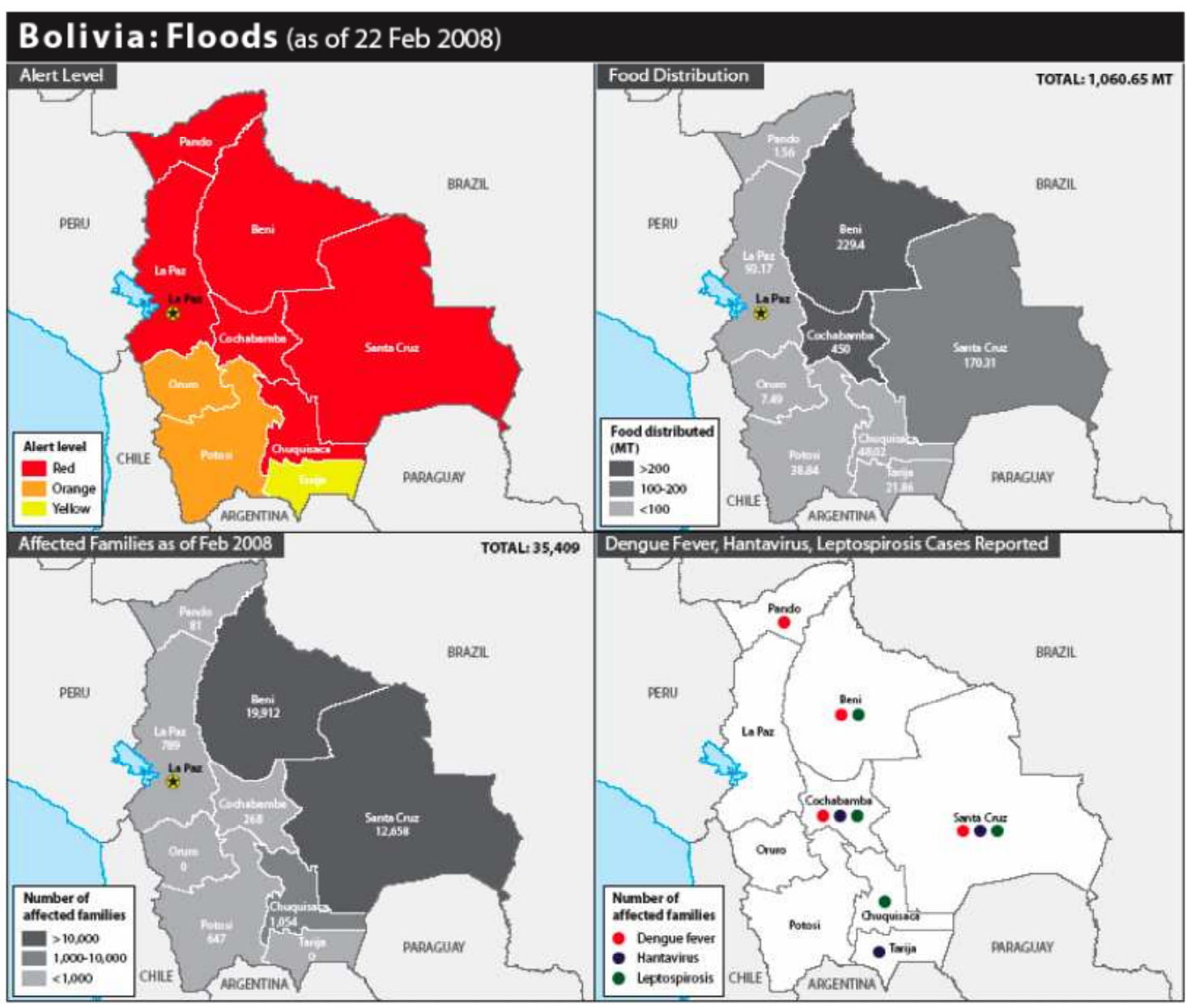

Bolivian Flood Assessment: retrieved $26^{\text {th }}$ of May, 2008, from: (OCHA, 2008b)

\subsection{Conclusion}

Before researching in Bolivia I had no comprehensive impression of its current situation and I was not sure about entering the country because of increasing news of violent conflicts resulting in three dead protesters. However conflicts slowed down in carnival season in January and February. After spending time in the country and witnessing the immense inequality, the poverty and the excess, the cultural diversity and the conditions of life and work in a so extremely diverse place, I felt of having a better understanding of what setting and environment the establishment of REDD measures in Bolivia are attempted. Being in the country's disaster zone I felt alienated and the diversity of problems, conflicts and interests overwhelmed me. However the struggle of the indigenous, the poor and their representative, Evo Morales, continues to being opposed by the interests of the eastern economic elite and their campaign against the new constitution. Hereby I can only express 
my respect for the ones working for peaceful solutions for a way out of the coercing inequality that divides Bolivia in these unstable times. 


\section{Bolivia's REDD Strategies}

\subsection{Introduction}

It is estimated that around $80 \%$ of Bolivia's Green House Gases (GHG) originate from the Land Use, Land Use Change and Forestry Sector (LULUCF) (Bojanic, 2001, p. 4). This confirms how important it is for Bolivia that REDD mechanisms are included under international agreements and that Bolivia and other rainforested countries have fair and equitable access to these climate change mitigation initiatives. This chapter will explore the development of Bolivias position in international climate change negotiations, the development of Bolivias National Climate Change Strategy and how these pushed to be included in FCPF REDD initiatives. Further the establishment of the FCPF will be further examined and discussed. The chapter will look at current developments under the FCPF mechanisms and will assess the actions taken by Bolivia to comply with these.

\subsection{Bolivia's Climate Change Strategy}

Bolivia signed and ratified the United Nations Framework Convention on Climate Change (UNFCCC) and the Kyoto Protocol. Since than Bolivia has followed the framework's and protocol's agreements for further implementation of climate change mitigation and adaptation incentives to create the base for sustainable development incentives in Bolivia (Bolivia, 2002). Bolivias interests for complying and interacting with the frameworks and protocols agreements were of two important natures. One is the necessity to act upon the potential effects of climate change on vulnerable Bolivian ecosystems, its people's livelihoods, and its economic performance. For the second, Bolivia, as other poor rain-forested countries, has stressed to include the use of forests as carbon sinks and to establish fair and equitable REDD mechanisms that could lead to sustainable development support for Bolivia (Bojanic, 2001, p. 7). However in the process of these negotiations the Bolivian National Climate Change Strategy (BNCCS) was developed to attract further commitment in multilateral and bilateral support 
for Bolivia's climate change related development efforts. The ongoing developing strategy additionally aims to enhance the adaptive capacity of institutions on all government levels, enhance climate change related education and aims to offer advice to the cross-institutional overall development objectives of Bolivia (Bolivia, 2002, p. 1).

The BNCCS outline for the time period between 2006-20012 has so far focused on establishing further participation of, under the UNFCCC promoted Clean Development Mechanism (CDM) projects, and to use these to establish sustainable development initiatives in primarily the energy and forestry sector (Ulloa V., 2008). This objective focused on the assessment and development of national and local level capacities to design, plan and implement further CDM or other orientated carbon-trading projects to attract foreign investment for climate change mitigation and adaptation measures. To achieve this it is attempted to enhance legal and market based frameworks, to increase institutional and professional capacity and to improve financial mechanisms to implement this objective. Secondly it is attempted to discover how CCM and CCA can be enhanced in the public and private sectors by facilitating education, building capacities, and promoting these. The third major objective focuses on the coordination of inter-sectoral and inter-institutional development and consultation on possible pilot incentives (PNCC, 2006; Ulloa V., 2008). Bearing in mind that due to Bolivias general poverty the national capacities for the needed adaptation and mitigation efforts are comparatively very low. Therefore Bolivia stresses in its climate change strategy and its communication with the UNFCCC "to find new reciprocity equity and commitment levels among lesser-industrialized countries and those countries that have, throughout history, contributed to the greenhouse effect through their emissions" (Bolivia, 2002, p. 2).

Even though Bolivia has created CDM projects and has benefited from these, overall the Clean Development Mechanism is not as locally profiting as wished for from a development countries perspective. CDMs seem to use a significant section of available funds and resources to create and operate markets in the industrial countries and therefore support the industrial countries economy. The actual support supplied by the CDM scheme under the UNFCCC has, from a development countries perspective, not sufficiently supplied the needed commitment and support to 
first; reduce significant greenhouse gases, and second; to implement needed adaptation measures to the vulnerable and poor in developing countries like Bolivia (Ulloa V., 2008). The negotiations around global CCM offer great opportunities to benefit countries like Bolivia. But in reality the actions, efforts and dedications are to date not adequate because climate change mitigation requires strong commitment that is not financially beneficial for and requires an attitude change in the industrial practices of the main emitting countries. CCM, in Bolivia, primarily focused on REDD, is not only the problem of resource rich countries like Bolivia, it is a global problem which acquires the strong commitment of the industrialised countries to really offer alternative development opportunities to developing countries like Bolivia (Ulloa V., 2008; Villanueva, 2008). And these will require a major wealth and resources flow towards countries like Bolivia to enable them to develop in a sustainable manner.

\subsection{Bolivia and the FCPF}

Following the in Chapter 3 mentioned development under UNFCCC negotiations that led to the inclusion of the REDD concept in International CCM measures, Bolivia worked towards possible future REDD mechanism. This was shaped by the fast evolving guidelines under the FCPF, also explained in chapter 3 . The first required data was reliant data on the land-use change, primarily done by assessing Bolivias forest cover with help from foreign specialists, as documented in killeen et al. (2007) and the work of the Superintendencia Forestal (Wachholtz, 2006).

However with the establishment of the FCPF and the establishment of its operational guidelines and capacity assessment templates Bolivia started to negotiate and apply to the FCPF procedures. The progressive step to establish this important institution led to the creation of two mechanisms the Readiness Mechanism and the Carbon Finance Mechanism under the FCPF. The Readiness Mechanism (RM) assists around 20 tropical and subtropical countries to prepare for future participation in the FCPF facilitated REDD efforts. The assistance aims to assess countries capacities in preparation of a national REDD strategy and to establish deforestation and forest degradation reference scenarios and baselines. This should lead to the further 
establishment of national REDD monitoring systems that allow carbon emission data predictions (Bosquet, 2007, p. 8).

When accepted by the FCPF Bolivia and approximately 4 other countries will be financed and supported to implement pilot activities under the Carbon Finance Mechanism (CFM). This will allow the country under control of their government to implement needed measures to achieve REDD and to henceforth work to integrate incentives that lead to a sustainable interaction between its forest resources and all forestry stakeholders. Being a substantial development mechanism with an estimated 11 billion US\$ per year, as stated above, has in some way potentially divided the stand of rain-forested countries in their common visions through the sudden need to compete for the offered funding incentives.

Thorough consultation of all major stakeholder groups was missing in the design of the FCPF and indigenous nations and CRNs are not imbedded into the governance structure of the FCPF to a substantial level (Wilson, 2007). My perception from the views of my research participants was that Bolivia welcomes the move forward towards development support that focuses on sustainable development solutions.

\subsection{The Readiness Assessment}

In the beginning of my research in La Paz I was invited to one of the meetings of the REDD Technical Committee, consisting of representatives of various governmental bodies, NGO and consultants, that were working on the Readiness Plan Idea Note (R-PIN). The Technical Committee REDD has been working on this during my research time in Bolivia and has completed the R-PIN in the following month. However $I$ was not able to use the gathered information under the R-PIN because it is an unpublished internal working paper that might be accessible after the FCPF will decide on Bolivias case. The R-PIN is a technical summary of interested countries' capacities, ideas and plans for future processes under the RM and CFM to allow the FCPF to gain an insight of the countries setting and development in REDD related issues (Seifert-Granzin, 2008b). These issues, as shown in the R-PIN Objectives, include an explanation of the major reasons and issues driving deforestation and influencing the forestry sector. Further it will include a preliminary assessment of Bolivias forest-area-management, land-use change, 
and GHG emission data. Further Bolivias climate change related institutions and governance bodies will be presented, the responsibilities of each will be elaborated upon and the legal framework will be explained. This will lead to an outline of Bolivias current strategies under the national climate change strategy, that will explain in further detail how the strategy will adapt to meet the objectives of REDD under FCPF funding in the future. Following this strategic outline the R-PIN is supposed to identify all major assistance needed to bring the planned developments into action.

The R-PIN appeared to be of great importance to advance the thorough assessment of the needs of developments for future CCM and sustainable development measures in Bolivia and to built collaboration between various stakeholders in the process of completing the R-PIN in the REDD Technical Committee. However the FCPF will decide on Bolivias R-PIN case in July and this will determine if Bolivia will be one of the 'lucky' 5 countries

\section{Readiness Plan Idea Note}

In the R-PIN the Country addresses the following issues based on available data and information:

- Statement of the deforestation and degradation problem: Information on the drivers and agents of deforestation and degradation; estimations of total land area subject to deforestation and degradation and resulting emission levels; and location and types of forest ecosystems.

- Responsibilities and legal framework: Roles of the relevant institutions and agencies (at federal, state and municipal levels) responsible for policy and program implementation and law enforcement, monitoring and promotion of sustainable land use strategies; legal framework for these activities; and designation of the national focal point for REDD activities.

- Current strategy: Description of the activities currently under implementation by the Government and stakeholders; challenges for further improvement; methods for measuring emissions, including uncertainties and data gaps; and description of the way that different stakeholders, including forestdependent indigenous peoples and other forest-dependent communities participate in the design and implementation of those strategies or national plans.

- Assistance requested: Listing of the areas where the country requests support from the Readiness Fund, including historical emissions and modeling of future emissions from deforestation and degradation; adoption or review of national REDD strategies; design and implementation of a Monitoring System; financial assistance for consultations with stakeholders; capacity building and technical assistance at different levels.

FCPF R-PIN Objectives: received on the $12^{\text {th }}$ of June, 2008, (FCPF, 2008, p. 17)

that will be included under the CFM and will therefore be eligible to receive further funding for the countries development proposal to achieve REDD on a significant scale (Seifert-Granzin, 2008b). 


\subsection{Local Participation in Bolivian REDD Strategies}

In its 'Presentation Booklet' of the FCPF it is stated that for the Reediness Mechanism indigenous and other forest dependent inhabitants will be meaningfully consulted (Bosquet, 2007, p. 7). The FCPF objective to involve all stakeholders as next steps in the process will require to educate, involve and consult primarily local and indigenous stakeholders about the current REDD development processes and the extent it might effect their local livelihoods. As stressed for by several NGO and indigenous representatives also the FCPF states this in their Information Memorandum that it "is of absolute importance as the knowledge on REDD is generally very limited" (2008, p. 22). From my knowledge no indigenous representative were involved in or even consulted for the R-PIN process at the time of my research but plans for this existed (Seifert-Granzin, 2008a). In May 2008 a workshop was held on REDD and the role of indigenes communities with representatives of the legal framework for Native Communal Lands (TOC), the Bolivian Indigenous Nations Organization (CIDOB) and other local forest inhabitant representatives (Seifert-Granzin, 2008b). However, partially due to the complexity and the needed academic education and participation in the REDD discourse I note here that from my perception neither on local level, in the preparation of the R-PIN, nor on global level, in the establishment of the FCPF, indigenous and local visions seem to have been integrated and respected to the by indigenous and NGO representatives requested extend (Hall, 2008). Nor has this important development mechanism, that might well, if given the needed commitment, grow to a major international development tool with wide reaching local and global impacts, achieved the necessary democratic participation in the planning and design of its internal structure and policies. Due to the importance of the local acceptance of the opportunity costs and the establishment of alternative local livelihood concepts, the needed in-depth-consultation process of local and indigenous community and the respected involvement of their visions of their future should be included in-depth as fast as possible. These are mentioned in the operational guidelines of the FCPF but seem yet not to be accomplished in the practical performance of these guidelines. 


\subsection{A view in the Future}

Taken that the referendum in August will not lead to a division of the country, Bolivia might, if accepted into the CFM and with help from the FCPF fund and technical assistance, move forward to begin to increasingly plan and implement their in the R-PIN suggested objectives to achieve REDD. This will extend the R-PIN assessment to become a Readiness Plan that will conceptualise the institutional and legal framework, the state of forest and land-use change policy and monitoring capacity, and the further timeline for cross-sectoral development strategies and implementation. Some doubt that Bolivia will make it due to institutional weakness, gaps in the assessment progress made under the R-PIN and the current unstable situation of the country (Seifert-Granzin, 2008a). This might lead to the acceptance of Bolivia into the Carbon Finance Mechanism that will start to supply sufficient resources to begin to implement the, in the Readiness Mechanism designed, development objectives under the CFM.

\subsubsection{The Readiness Plan}

The constantly evolving development efforts under REDD strategies, will attempt the challenge to change the current difficult and complex interaction of poverty, corruption, political instability, foreign, private sector and indigenes peoples interests in Bolivian resources. This will require a strong effort to establish cross-sectoral collaboration by various stakeholders. As shown in the Readiness Plan graph the two next steps will be to parallel establish capacities and strategies, educate and consult and assess and monitor current developments in the land-use change.

The first analytical step of the Readiness Plan will require sound reference scenarios and assess the main

\section{Readiness Plan}

The Readiness Plan elaborates on the R-PIN and contains more detailed information on the country's forest policy, including the legal and institutional framework, the country's monitoring system, and its strategy to reach Readiness. It would include concrete terms of reference for the elaboration of the REDD strategy; describe the details of the stakeholder consultation process including how to involve affected communities, indigenous peoples and forest dwellers. The Plan would present approaches a country would consider to elaborate on the reference scenario and the monitoring strategy design. The Readiness Plan would further include an implementation schedule and would outline clear responsibilities and milestones. The Readiness Plan would also include a communications and outreach plan.

FCPF Readiness Plan: received on the $12^{\text {th }}$ of June, 2008, (FCPF, 2008, p. 18) 
reasons for deforestation in Bolivia, and fill gaps in the needed land-use change data sets. Strategically it will be important to analyse, governance, policy, and legal framework solutions by further collaboration and consultation between various stakeholder to identify the needed policy changes and strategic objectives. Further it will be analysed how monitoring over REDD development processes can be achieved for forest management changes and governance implementation. The second step will than lead to the implementation of monitoring mechanisms and further identification of institutional and policy reforms. The analytical conclusion of the first phase will than be thoroughly evaluated and reviewed by various stakeholders and this will define the final design that will form the Readiness Plan (FCPF, 2008). How democratically, participatory and in what depth local consultation will influence government policies will depends on the monitoring and governance structure within the RM and CFM strategies on local level and on the FCPF safeguard mechanisms. 


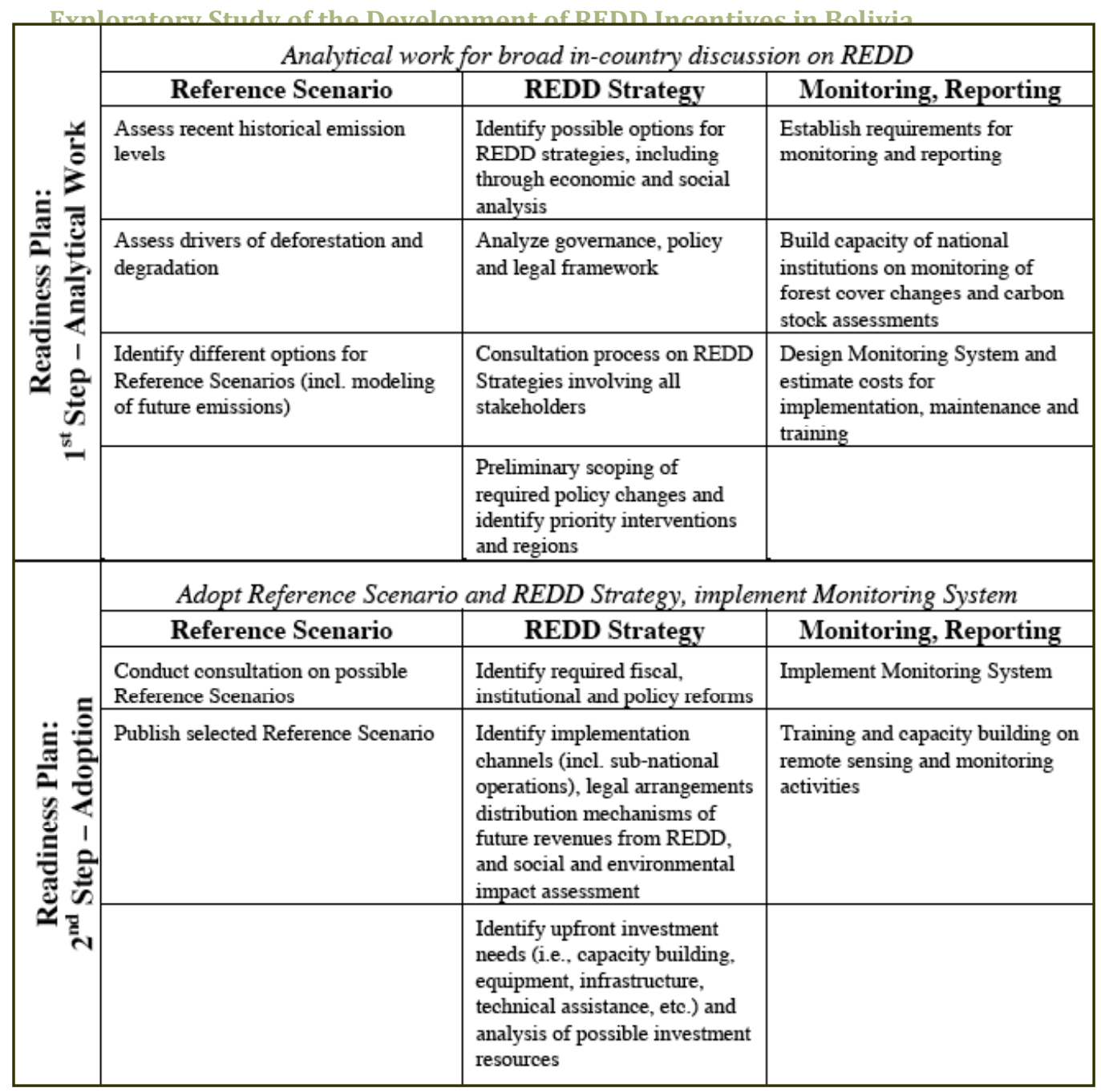

FCPF Guidline Steps for REDD in Participant Countries under Readiness Plan:

received on the $12^{\text {th }}$ of June, 2008, (FCPF, 2008, p. 20)

\subsubsection{The Carbon Finance Mechanism}

The participant countries whose Readiness Plans will be accepted under the FCPF will be invited to voluntarily submit proposals for Emission Reduction Programs (ER Program). If accepted, Bolivia will be able to submit ER Programs that are based on and imbedded in the defined strategies in the Readiness Plan. In the CFM Operation Agreement it is stated that the submitted programs will than be checked for basic approval under the Facility Management Team (FMT). It will than be reviewed by the Technical Advisory Panel that will approve it if found technically viable and passed on to the Carbon Fund Participant Committee. These will decide if the ER will become part of the CFM portfolio for the specific country and will, together with the trustee (the IBRD of the World Bank Group), decide under what funding Tranche (a certain funding sector) the $E R$ will be accepted. If it is than 
included in a funding Tranche it will be checked on wether it complies with the environmental and social safeguard policies of the FCPF. After the submitted ER has been assessed by an independent review the ER will than be included in an Emissions Reduction Payment Agreement (ERPA) that will signed between the participating approved entity or government and the IBRD (FCPF, 2008, p. 28). From than on the participating entity or government will implement the Emission Reduction Program and is asked to report back on an annual basis. Independent reviews will confirm the emission reductions, claimed by the participating entity. The trustee of the Carbon Fund, the IBRD, the Bretton and Woods institution that was built up together with the IMF to rebuild Europe, will than ensure that the implemented ER is still in compliance with the environmental and social safeguards policies of the FCPF. And based on this monitoring procedure the trustee, the IBRD will pay the participant the accounted monetary emission reduction amount (FCPF, 2008, p. 29).

The types of ER Programs that Bolivia will be able to receive funding for are defined under the operating Agreement of the Carbon Finance Mechanism shown in complete detail in Annex I. These are defined into four major areas; general economic policies and regulations, forest policies and regulations, forest management and rural development and can be implemented on national, sub-national, or local level. The possibilities that arise from this FCPF definition are in. For the Value of ER payment it is not the amount needed to achieve the reduction of emission but will be set by international carbon markets and will depend on the further development on REDD negotiations under the UNFCCC. It is further said that all important, reviews, assessments documents and materials concerning the safeguarding of environmental and social issues in the implementation of Emission Reduction Programs will be made public in the World Bank Group's Info-shop in Washington and in the relevant national information office in the participant country. Further information on safeguarding policies for the implementation of ERs under the CFM was not included in the FCPFs Information Memorandum at this stage. 


\subsection{Conclusion}

In conclusion, the progress made in Bolivia to deal with possible wide-reaching development support has been significantly increased through the analysis under the R-PIN. Progressively the collaboration under the FCPF Readiness Mechanism has improve the country's capabilities to further plan and design appropriate strategies that aim to decrease the rates of deforestation. As shown in land-use change monitoring Bolivia has already needed capacities that will help to build the base for further implementation of institutional development and governance enhancement. Excepting Bolivia's current instability, it shows that various aspects in forest management and governance will lead me to the conclusion that Bolivia has a good chance of being one of the five countries to be accepted into the CFM.

At the current state all proactive progress deserves acknowledgement after decades of partial ignorance. But the undemocratic nature of the design and development of the Readiness Mechanism under the establishment of the FCPF should not be forgotten. Though the FCPF aims to push the local governments to ensure the implementation of the mechanism's safeguard guidelines in the ER Programs it will take a lot top narrow the gap between visions from the banks and visions from the forests. I am hopeful that the educated and city-based designers and planners of further REDD strategy in Bolivia will not fail to assure the participation of indigenous and local visions in its REDD strategies to contribute to unify efforts to achieve REDD. 


\section{Challenges in the Achievement of REDD in Bolivia}

\subsection{Introduction}

This chapter will explore the various challenges that current and future REDD strategies face in the achievement of developing an increasingly sustainable interaction of all REDD stakeholders with Bolivia forest resources and wild forest ecosystems. These challenges are of diverse nature and therefore this research will focus on the challenges that have been communicated by the research participants and current literature on the topic. However it is not in the scope of this research to examine these different challenges into depth. Moreover this research aims to define these in an exploratory fashion to offer an overview of the complexity of the attempted development challenges and to thereby define further research objectives.

\subsection{Basic Needs}

As shown in chapter three Bolivia is the poorest country of South America. In some place climate change is already undermining the efforts to fight poverty due to climatic instability's impact on poor peoples livelihood (UNDP, 2007). The very heavy floods that I experienced in January were part of known

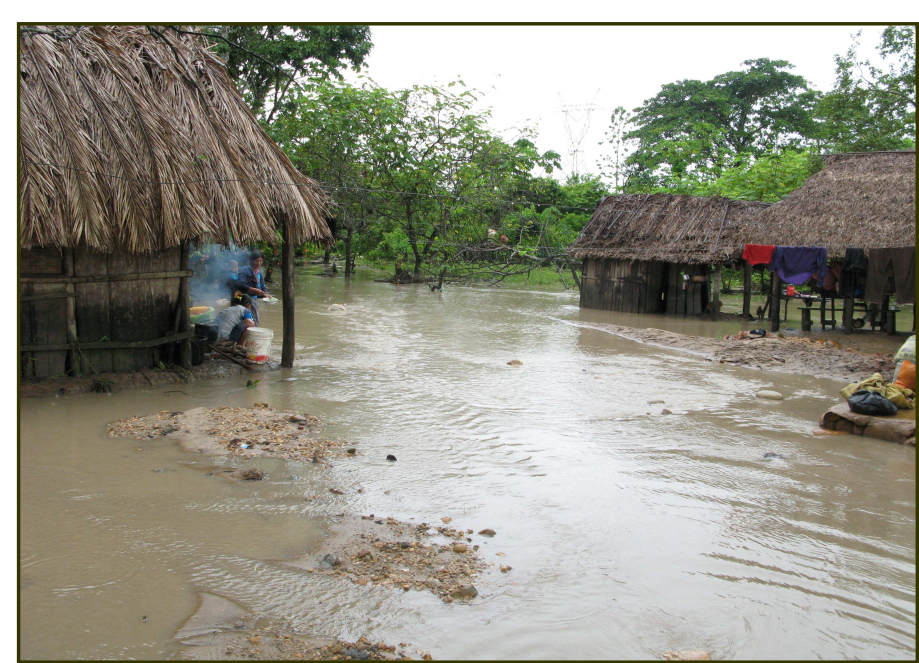

A flooded village near Santa Cruz: $\odot$ Jannes Stoppel, Jan. 2007.

climate patterns but their intensity will increasingly destroye people's livelihoods and their efforts to make a better living. For the people I met, mostly rural farmers, when I was stuck in the floods showed me how important climatic stability and how devastating the increase of severe weather events is for the majority of mostly poor, rural, populations around the planet. 
This was the case in Bolivia and is apparent in most other nations with great rural populations and dependence. It is not that the floods came by surprise because local populations and ecosystems are adapted to the strong rains in this part of the year. It is the strength of these climatic irregularities that decide over the survival of crops, the impact it has on the basic infrastructure and therefore over the livelihood of these populations. These peoples livelihood primarily depend on the survival of their crops and therefore climate change, primarily caused by the emissions of the historically most emitting countries, endangers their excess to their basic needs. It appears to be the fate of the poor that they will be hit by the action and excess of the industrialised countries again. The poor, the exploited, will suffer first under any climate change effect, and it is them that need urgent support to deal with their future. The importance to address these global injustice issues in the process of sustainably achieving REDD in these countries seems inevitable (Timmons Roberts, 2007). And more so the establishment of REDD incentives offers the opportunity to focus on the betterment of rural capacities to adapt and to use this support to offer poverty elevation measures. This could be seen as reimbursement effort of the historically most emitting countries for their unjust state of development and offer the rural poor in Bolivia and elsewhere the dignity to live in considerable security with the effects of climatic instability primarily induced by the developed countries. In the future participation processes to assess the perspectives, needs and opportunity costs of local communities for further implementation of ER programs it should be seen as primary objective to react on local basic needs. ER programs should then fulfil these basic needs by linking climate change mitigation with climate change adaptation and sustainable community development measures in their design, planning and implementation phases (Ribera, 2008).

\section{3 Valuation of REDD}

The local price of REDD is estimated by the needed and demanded 'opportunity costs'. This means the amount of monetary or nonmonetary value that an entity needs or demands to be persuade to an alternative livelihood other than the dependency on deforestation or forest degradation. These needs or demands are 
seen as the price of REDD achievement on the ground. However this price varies from case to case. It depends on the size of the local entity or community, their needs and demands and the development standard they live in. This is often dependant on how close the entity or community is to the next city or industry centre how the employment opportunities are in the region and how much corruption is involved in local forestry practices (Paz, 2008). The list is long and the matter of defining these opportunity costs is difficult due to the evolving nature of opportunity costs. Once an entity has accepted the agreed opportunity costs to end deforestation the opportunity cost will rise with the development of the community. Therefore any national strategies and funding mechanisms need to acknowledge and integrate the flexibility needed to react and adapt to these local needs and demands. The international price might be $20 \$$ US for a ton of carbon, but on the ground it will depend on the circumstances of the local community, on how much is needed to supply development that offers enough incentive to decrease deforestation (Ulloa V., 2008). However if the demands of local participants and local entities will not be respected and the process of defining the opportunity costs will not happen in a participatory bottom-totop approach the sustainability of planned alternative might be endangered from the start (Kaimowitz, 2007; Stearman, 2006). It will be one of the main challenges to assess the opportunity costs, increase institutional flexibility to allocate the needed resources and to meet the local needs and demands in a satisfying manner (Ulloa V., 2008). How these costs are most sustainably and most respectfully defined still needs further research. However there have been significant research attempts in the Noel Kempff Mercado Climate Action Project and by several incentives that experimented with Payments for Environmental Services (PES) (Asquith, 2001; Wunder, 2006, 2007). What is important to consider is that if the CRNs will come to a point in which the costs of REDD are sufficiently set, it will offer an opportunity to form a alliance to further negotiate this price if it stays more economically viable on the carbon market than other REDD options (Paz, 2008). Back to the problem, I think the current market system is not sufficiently regulated to deal with the urgency of the problems of human interaction within the earthsystem. Nor have humans established an international good-governing institution that can direct needed funding sufficiently without a market based funding system that 
is set up for the interests of greed (Schumacher, 1999). It should by all means be avoided to primarily focus on the market rule 'cheap is best' because in this case the opportunity costs will not speak the truth about local needs and will therefore not be sustainably viable. Primarily the sustainable development of forest people, their needs and demands should set the price to achieve REDD (Ribera, 2008).

\subsection{Common Vision}

As in international climate change negotiations, REDD efforts in Bolivia are troubled by the lack of a common vision. In a time of autonomy debates that could further deepen the divide in the country it is hard to imagine common vision for REDD to prevail through the coming political developments. The country's issue of cultural difference between Andean indigenous power and Spanish ancestral supremacy is a hard setting, even for the most conservative development concept. At current times the country does not stand united but struggles over the establishment of justice, equal rights and condition of life for the mainly indigenous, poor and on the other hand for the continuity of post-colonial power structures for the benefit of the rich elite (Caroll, 2008). Focused on conservation issues these visionary differences are experienced in foreign funded projects by the commitments of local stakeholders and workers due to the imposed nature of some of these programs (Wachholtz, 2008a). The historic unequal social structures and roles are imbedded in this partial apathy to work with a common vision towards the implementations of further REDD projects because it is not the local, the poor that is designing, but the foreign, rich that is pressing for forest conservation and for emission reduction. Local education and participation plays a crucial role to narrow the gap towards a common vision for REDD projects in Bolivia. And for future designing processes in the arenas of international, national and regional climate change issues the in-depth participation in design of the future of forest people should be of high importance to build this common vision. However the amount of already sustainable and communally managed forest resources gives hope that this will lead to further incentives that combine forest industries economic intentions 
with forest inhabitants needs for livelihood security and the global need for biodiversity conservation and REDD.

\subsection{Participation}

I failed to gather the most important visions on the challenges of REDD, the visions from the ones that can only participate in govt and academic planning and designing discourses if they are approached to participate. If not asked they will not know what is being planned for their future and how these strategies will effect their local realities. The failure of addressing local and indigenous participation in this research has influenced my perception and I am aware of this. However I tried to give these ungathered visions a voice through the involvement of other representatives of their perspectives. As shown in 'Visions from the forests' in chapter three the scale of local and indigenous participation in the current REDD development process under the FCPF mechanisms and in the governance of the FCPF is failing to respect forest people's visions about their future. As shown in various studies on the subject (Miranda, 2006; Murdiyarso, 2006; Robertson, 2005) it is of high importance to improve the space for local participation but desirably even the local incentive for design and planning of local futures. The Bolivia case might be advanced in knowledge about forest conservation with community participation, but it is yet to see how in-depth the demands, needs and desires will shape, or will be allowed to shape the designs and plans for potential ER programs.

For the international governance body, the FCPF it is also suggested to increase this participation from local people over the decisions that shape local futures. But it is hard to imagine that the World Bank controlled FCPF and it's development mechanisms would allow a truly democratic governance structure that give representatives of all stakeholders equal rights to vote on the decisions that shape local forest futures. However I think this is highly desirable. Further I extend this personal desire on the governance structures of all international governing institutions. The funding input for World Bank, the United Nations and others should not be directed by the main funding bodies of these institutions, but should consist of democratic governance that allows participation and equal voting rights of all stakeholders. As Timmons Roberts argues it is already exclusive, the opposite of securing participations from 
all stakeholders, to allow negotiations under the UNFCCC where the rich countries can negotiate with great team of negotiators and lawyers and small states can barely afford the airfare to allow one person to attend the meeting. On global level just governance structures in international institutions are needed to support truly international governance and therefore true participation of disadvantaged stakeholders (Timmons Roberts, 2007).

\subsection{Institutional Capacity and Corruption}

For the establishment of REDD strategies in Bolivia it is absolutely vital to build institution capacities (Ulloa V., 2008). Primarily this might be important to build capacities in the staff of implementing institutions on national and municipal level to strengthen the understanding and ability to implement the planned ER programs under the FCPF. Policy changes, legal frameworks and sustainable development and monitoring and law enforcement will all require trained and knowledgeable staff to implement the planned changes. This is applicable to all levels of institutions (Ribera, 2008) but primarily on municipal level (Wachholtz, 2008a) the needed capacities and needed education is of great importance to assure the ability to direct regulatory and controlling responsibilities to municipal institutions. This has been already, comparatively to fellow CRNs, achieved to a satisfying extent due to primarily MODIS satellite assessment of land-use change and the work of the Superintendencia Forestal in Bolivia. The extent to what deforestation data is already available exceeds by far the development of institutional capacity to act upon it sufficiently (Paz, 2008; Wachholtz, 2008a). As Wachholtz was pointing out the Superintendencia Forestal (the institution responsible to monitor deforestation and coordinate law enforcement) has 160 staff that are to monitor and coordinate the control of over 50 million ha of forests that indigenous people, traditional Hispanic residents, recent immigrants and industrial enterprises backed by foreign capital are competing about (Killeen, 2007). It must be pointed out that the superintendencia is not able to rely on local capacities and to direct more control to act upon their coherent deforestation data that is made available to local municipal institutions. Therefore the need to focus on assessing the various actors of corruption in law enforcement of illegal 
deforestation on a municipal level needs to be urgenty addressed. To develop the institutional capacities to confront especially the $1 \%$ of primarily industrial actors of deforestation that is responsible for 30-40\% of all deforestation in Bolivia by enhance the integrity of land-use change governance through law enforcement, extend municipal control and reduction of corruption in prosecution processes should be of high priority (Wachholtz, 2008a). Compared to the 15\% of small-scale deforestation of farmers partially driven by need of migrants from the poor Andean highland to the forests in the east who are in need of new agricultural lands.

\subsection{Political Stability}

As described above Bolivia stands at a unstable point in history where the post-colonial past has formed a revolutionary movement for better social services, less resource exploitation to benefit primarily the rich and stronger recognition of indigenous culture (Prashad, 2006). However this process of Morale's attempt to push through a new constitution that focused on the mentions objectives created a growing powerful opposition in the leading economic elite based in the eastern lowlands, Santa Cruz. The emerging resistance by the old economic elite and their hierarchical power networks throughout the lowlands have formed a powerful campaign against Andean indigenous power, influence, and claims for the resource wealth of the eastern lowlands (Dangl, 2007). Therefore the current government is trying to define a course that meets the interests of the poor and indigenous population and that meets the Bolivian needs to boost economic development through funding of new infrastructure like a South American road plan to increase the transport connection of various countries (Ribera, 2008). The current political situation is very complex with many compromises to be made to keep Bolivia peacefully together. However the attempt to boost and enhance poor and indigenous rights, livelihoods, and social security is needed. Therefore, in the current situation it is difficult to rely on political stability of policy changes (Ulloa V., 2008). One can only hope that Bolivia will find peaceful compromises that will bring the needed pro-poor, proindigenous, and environmental compatible political changes. 


\subsection{Conclusion}

Developing and industrial countries both see that it is worth to try the implementation of REDD incentives and that it will offer many co-benefits but the question remains if this can be achieved in a sustainable manner. The scope of this research has been to explore the challenges in the implementation of the planned REDD mechanisms in Bolivia, but as demonstrated the research could not comprehensively report on them in full depth. Bolivia as one of many countries applying for the offered mechanisms under the FCPF has great potential in the areas of community-based conservation, compensated conservation and forest monitoring. These experiences will help to progressively address many of the remaining problems that Bolivia face in the potential implementation of the FCPF carbon finance mechanism. Comprehensive research, exploratory studies, and pilot activities are needed in the various areas that challenge the implementation of the developed REDD strategies and plans in Bolivia. 


\section{Concluding Thoughts}

\subsection{Introduction}

At the start this research aimed for the creation and contribution of knowledge needed to create fair and participatory REDD exchange incentives in Bolivia. I set out to gather visions from a cross-section of society, from govt sector, NGOs, local institutions, and indigenous and local forest inhabitants, about their visions on how large-scale REDD mechanisms could look like. The focus changed and I adapted by asking about the major challenges and visions in the currently approached implementation of the FCPF mechanisms. This changed the aim from being a primary proactive contribution of knowledge to an evaluation of observed REDD development knowledge.

This dissertation is the outcome of the analysis of gathered perspectives, a thorough secondary data review, an observation of current international REDD negotiations and my own perceptions of the urgencies in geo-politics and a passion for the remaining old-growth forests and their people. I collected valuable primary data from govt and NGO representatives and aimed to establish a broadened vision of the surrounding issues that shaped the environment for the implementation of REDD strategies. I found myself examining a very complex development challenge that exceeded my abilities to profoundly examine and evaluate all surrounding international, national, and local issues of climate injustice, social equity and political instability in the development of REDD in Bolivia. This exploratory study does however provide an overview of the complex development challenges of REDD in Bolivia and the way it is shaped by international influences and settings.

\subsection{Bolivia's REDD strategies}

As with many other CRNs, Bolivia offers great opportunities for the implementation of the FCPF mechanisms. And as shown in chapter three, the amount of forest for possible large-scale pilot projects and the increasing rates of deforestation are 
identifying Bolivia as a CRN with great potential and great need for further REDD efforts (Killeen, 2007; Seifert-Granzin, 2008a). However the socio-political situation and the apparent poverty, as stated in chapter four, constitute an atmosphere of political and social instability and this could be seen as negative presetting for the allocating of FCPF funding under the CFM. As put forward, the amount of forest monitoring data and the institutional capacity in forest monitoring is comparatively high and would be a solid base for any further REDD baseline for further ER programs (Paz, 2008; Wachholtz, 2008a). The amount of education and capacity building needed to develop a crosssectoral understanding of the REDD strategies and its implications will take thorough cross-sectoral effort. This is needed to assure primarily local stakeholder understanding of the REDD concept and to therefore assure their ability to actively participate in the national REDD discourse. If Bolivia will be accepted under the CFM, the sustainability of ER programs will depend on the compliance of the conceptualised implementation plans with the needs, demands, and visions from local stakeholders. Without the assurance of this compliance the govt-designed programs might be confronted by local disagreement over the implemented development measures sooner or later after, endangering the sustainability and the security of the ER programs' objectives. I am confident though that the team of the Technical Committee REDD (the group of specialists working on the development of Readiness Plan and further design of REDD development measures) is aware of the importance of local participation in design and implementation phases due to the extent of practical field experience in Bolivian Forests.

Given the political situation of the country, peaceful solutions that will strengthen poor and indigenous rights and lessen the unacceptable inequality in the county are to be hoped for. For it is these issues of inequality that could be seen as one objective of the REDD mechanisms. REDD in Bolivia does not only offer the opportunity to protect vast amounts of its pristine ecosystems from human destruction but also offers the opportunity for poor countries to be supported in developing sustainable future solutions. Bolivia since the Spanish conquest has been exploited for their resources. As many other CRNs Bolivia deserves honest and unconditional support to be able to protect their forest ecosystems for the greater good of the global climate. This effort of a country, as climate change vulnerable as Bolivia needs to be, needs to be valued and 
respected by international negotiations and must be shown in the commitments of support by the historically most emitting countries.

\subsection{REDD and International Climate Change Negotiation}

To research the REDD strategy developments in Bolivia an overview of international REDD negotiations was needed. This scoping exercise of the international discourse on how to achieve this complex issue on the ground was overshadowed by the broader context of global issues of climate justice in CCM negotiations. These issues of injustice of cause and effects of climate change, additionally supplied reasons to highlight the need for stronger commitments of the most emitting countries and greater involvement in international negotiations by strengthened leadership and recognition of poor countries that will bear the effects of climate change first. Bolivia, as a vulnerable and strongly effected CRN, should be strongly encouraged to strengthen its ties within the coalition of Rainforest Nations to remain a common force in the negotiations about future REDD financing and trading mechanisms. This common interest should not be undermined by any means through the created competition under the FCPF funding schemes. Because protected forests are a growing economic resource that will imply costs and that need a value. The costs, by assessing the local opportunity costs, of achieving REDD are, to an extent, set by the local preconditions. The price will be different though and will depend on international negotiations and market forces. If the CRN can form a common vision, a common argument and a common position in future international REDD negotiations about funding measures and allocation of resources they can take a stronger lead to set the value of REDD in CRNs. Bolivia, as other poor countries should therefore not adopt a defensive recipient role in the international governance of REDD development but should instead take a demanding lead. 
I see the REDD effort as well as other CCM measures part of a needed redirection of resources that should become a major reimbursement effort for the historically most emitting countries to repay

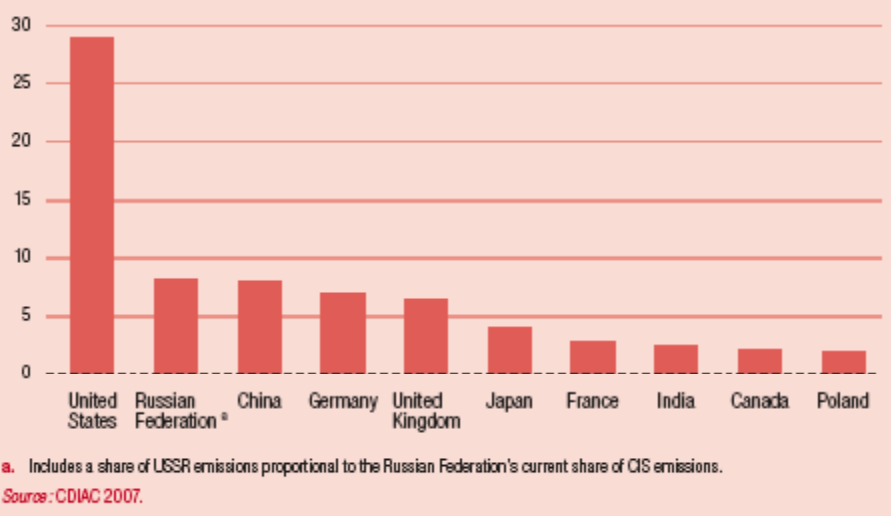

Injustice of $\mathbf{C O}^{2}$ emissions: received on the $23^{\text {rd }}$ of May from: http://hdr.undp.org/en/media/hdr_20072008_en_complete.pdf

their debt of colonial and post-colonial exploitation of the poor and the environment. But yet too often, the economic and geo-political interests of the leading 'developed' countries influence the current climate change negotiations and agreements. The division of CRN common perspectives through competition under the FCPF could partial lead to the division of the Nations of the Rainforest Coalition negotiating power and decrease its ability to argue for example for changes in the FCPF governance structure, decision making on ER programs or for the role of CRNs emission reduction under REDD in future post Kyoto agreements. The post-Kyoto agreement must for once set drastic guidelines for the historically most emitting countries to repay for their wealth through excessive resource use. So far resource wars and conflicts beat the need for vital transformations of human interaction with the worlds ecosystems. But climate justice, common vision and ecological integral understanding is needed for once, to achieve meaningful prevention of the worst (Timmons Roberts, 2007).

\subsection{REDD Back Home}

For a common vision it is essential that all stakeholders develop an awareness of their responsibility of the problem. As shown in Bolivia the drivers and stakeholders of deforestation are diverse in nature. Poor Bolivian farmers have not got much choice but to slash and burn to make room for crops. For the CEOs of the trading corporations who export the agricultural products to, for example, Europe, it appears to be not anything else but business. For the end consumer in industrialised societies it is primarily to extend their comfortable lifestyle, by eating meat that has been farmed on, for example, Brazil's 
deforested lands, or by buying and building with non sustainably certified hardwoods products from Indonesia. This study does not want to delve into the problems of the globalising unfair world market system but the need to see 'developed' societies, as vital part of the problem and as deforestation drivers is inevitable. It is their market signal that partially drives the deforestation of our remaining old-growth forest overseas.

The main deforestation driver is, in the end, the consumer behaviour in a market dominated world. It is the economic incentive to supply the demand of the excessively consuming levels of society, that creates the market signals that are set and controlled from the primary industrialised countries' trade regulations. I would like to stress that without the strong and urgent action and incentives needed to create sustainable consumer behaviour in 'educated' industrial societies all REDD efforts are like swimming against a stream. A stream that should form a common planetary effort to achieve great scale REDD for the integrity of our remaining wild forest habitats and its inhabitants and to mitigate severe climate instability.

It has been demanded by environmental NGOs for a long time and it needs a certain will to set trade regulations in place that will regulate the sustainability of what we consume. This must be achieved to close the cycle to commonly work towards the achievement of REDD (Greenpeace, 2006). However it is a great challenge to ask for in 'developed' societies that have so often exported problems of primary resource production and linked environmental exploitation.

\subsection{Final Remarks}

Some say that actions are harder than words (Bosten, 2008, p. vii). But I believe there are no excuses for the urgently needed action on climate change mitigation because an unstable climate means misery for the children of tomorrow. Even more it will be the poor and the vulnerable that will suffer first. Precautionary politics need to settle in to assure humans ability to save guard the future and not to waste it.

What are the 'developed' values that promote greedy egocentrism induced by apathy and shortsightedness in the name of economic growth and exploitation? Many people have accumulated insane 
amounts of private wealth through the economic system that has shadowed the most vital calls for change. World's leaderships followed the drive for maximisation of personal profits before leading humans to secure sustainable guardians and use of resources to supply livelihood security for all and secure this for future generations.

The Brundtland Report should have made it clear. We need urgent action for the sake of the poor and vulnerable, for the generations of tomorrow and for the integrity of the world's ecosystems. A change of values and a transformation from anthropocentrism to earthcentrism is urgently needed to halt the spread of greed as the most desirable value and to understand humans' responsibility as one inhabitant species of planet Earth. 


\section{References}

Asquith, N.M., Vargas Rios, M.T. and Smith, J. (2001). Can forestprotection carbon projects improve rural livelihoods? Analysis of the Noel Kempff Mercado Climate Action Project, Bolivia. Mitigation and Adaptation Strategies for Global Change, 7, 323-337.

Bojanic, A.H. (2001). Bolivia's Participation in the UN Framework on Climate Change. London: Overseas Development Institue.

Bolivia, Republic, C.A., Rica, C., et al. (2007). Submission of Views. Reducing Emissions from Deforestation in Developing Countries: Approaches to Stimulate Action. Paper presented at the COP 11. Access 2007 .

Bolivia, G. (2002). National Climate Change Program. Retrieved. from.

Bosquet, B. and Aquino, A.R. (2007). Forest Carbon Partnership Facility. A Framework for Piloting Activities to Reduce Emissions from Deforestation and Forest Degradation. Washington: World Bank.

Bosten, J. (Ed.). (2008). Towards a New Global Climate Treaty. Looking Beyond 2012. Wellington Institute of Policy Studies. School of Government. Victoria University of Wellington.

Boyd, E., Gutierrez, M. and Chang, M. (2007). Small-scale forest carbon project: Adapting CDM to low-income communities. Global Environmental Change, $17(2)$, 250-259.

Brennan, A. and Lo, Y.S. (2008). Environmental Ethics. Stanford Encyclopedia of Philosophy.Retrieved 20th of May, 2008, from http://plato.stanford.edu/entries/ethics-environmental/

Browne (2006). Aid \& Influence. Do Donors Help or Hinder? London: Earthscan.

Brydon, L. (2006). Ethical Practices in Doing Development Research. In V. Desai, et al. (Eds.), Doing Development Research. London: SAGE Publications.

Caroll, R. and Schipani, A. (2008). Autonomy poll threatens to derail Bolivia's revolution [Electronic Version]. Retrieved 4th of June from http://www.guardian.co.uk/world/2008/may/03/bolivia/print.

Chambers, R. (2005). Ideas for Development. London.

COICA (2005). Returning to the Maloca. Quito, Peru: Coordinator of Indigenous Organizations of the Amazon Basin,.

CRN, C.O.R.N. (2007). Submission of Views, COP 11. Vanuatu: UNFCCC.

Czebiniak, R.P. and Breitkopf, S. (2007). Consultation with NGOs - with Greenpeace: FCPF. from http://carbonfinance.org/Router. cfm?Page =FCPF\&FID=34267\&ItemID =34267\&ft=Doc Lib\&CatalogID $=37878$ 
Dangl, B. (2007). The Price of Fire. Resource Wars and Social Movements in Boliva. Oakland AK Press.

Davis, C. (2008). Protecting Forests to Save the Climate: REDD Challenges and Opportunities. Earth Trends.Retrieved 12.05, 2008, from http://earthtrends.wri.org/updates/node/303

Devall, B. (2001). The Deep, Long-Range Ecology Movement. 1960-2000 - A Review. Ethics \& The Environment, 6(1), 18-41.

FAO (2007). State of the World's Forest Rome: Food and Agriculture Organisation of the United Nations, FAO.

FCPF (2008). Information Memorandum. Washington, USA: Forest Carbon Partnership Facility. . from http://carbonfinance.org/docs/FCPF_Info_Memo_05-30-08.pdf

Fearnside, P.M. (2005). Deforestation in Brazilian Amazonia: History, rates, and consequences. Conservation Biology, 19(3), 680-688.

FERN (2008). Bali Special. Issue 123.Retrieved 11th of May, 2008, from http://www.fern.org/media/documents/document 40994102 .htm

FPP (2008). The Forest Carbon Partnership Facility: Facilitating the weakening of indigenous peoples' rights to land and resources. Moreton-inMarsh: Forest Peoples Programme.

Greenpeace (2006). Controlling Timber Imports into the EU. Joint NGO Statement. Amsterdam: Greenpeace International. Retrieved 4th of May, 2008, from http://www.greenpeace.org/international/press/reports/controllingtimber-imports-int-2

Grieg-Gran, M. (2006a). is tackling deforestation a cost effective mitigation approach? London: International Institute for Environment and Development. IIED.

Grieg-Gran, M. (2006b). The Cost of Deforestation. Report prepared for the Stern Review of the Economics of Climate Change. London: International Institute for Environment and Development.

Grieg-Gran, M., Porras, I. and Wunder, S. (2005). How can market mechanisms for forest environmental services help the poor? Preliminary lessons from Latin America. World Development, $33(9), 1511-1527$.

Griffiths, T. (2007). Seeing 'RED'? 'Avoided Deforestation' and the rights of Indigenous People and local communities Forest People Programme.

Hall, R. (2008). REDD versus People. Retrieved 16th of June, 2008. from http://unfccc.meta-

fusion.com/kongresse/SB28/downl/080602_SB28_RonnieHall.pdf.

ICFRE (2007). Views from ICFRE, Dehra Dun, India (an Observer organization) to UNFCCC on REDD. Dehra Dun: Indian Council of Forestry Research \& Education. Ministry of Environment \& Forests, Govt. of India.

IMF (2008). Bolivia and the IMF.Retrieved 28th of May, 2008, from http://www.imf.org/external/country/BOL/index.htm 
IPCC, I.P.O.C.C. (2001). Synthesis Report. A Contribution of Working Groups I, II and III to the Third Assessment Report on the IPCC. Cambridge Cambridge University Press

Johnston, R.J., Gregory, D., Pratt, G., et al. (Eds.). (2000). The Dictionary of Human Geography. Oxford: Blackwell Publishers Ltd.

Kaimowitz, D. and Sheil, D. (2007). Conserving What and for Whom? Why Conservation Should Help Meet Basic Human Needs in the Tropics. Biotropica, $39(5), 567-574$.

Killeen, T.J., Calderon, V., Soria, L., et al. (2007). Thirty Years of Land-Cover Change in Bolivia: Royal Swedish Academy of Sciences.

Kump, L.R., Kastings, J.F. and Crane, R.G. (2004). The Earth System (Second Edition ed.). New Jersey: Pearson Education Inc.

Mansvelt, J. and L.D., B. (2005). Writing Qualitative Geographies, Constructing Geographical Knowledges. . In I. Hay (Ed.), Qualitative research methods in human geography (pp. 248-265). South Melbourne, Vic. New York: Oxford University Press.

Mayoux, L. (2006). Quantitative, Qualitative or Participatory? Which Method, for What and When? In V. Desai, et al. (Eds.), Doing Development Research (pp. 115-129). London: SAGE Publications.

Miles, L. (2007). Reducing Emissions from Deforestation: global mechanisms, conservation and livelihoods. Cambridge, UK: UNEP World Conservation Monitoring Centre.

Ministry of Sustainable Development and Planning (2002). National Climate Change Program. Retrieved. from.

Miranda, M., Dieperink, C. and Glasbergen, P. (2006). Costa Rican environmental service payments: The use of a financial instrument in participatory forest management. Environmental Management, 38(4), 562-571.

Murdiyarso, D. (2005). Carbon Forestry. Who will benefit? Jakarta: Center for International Forestry Research.

Murdiyarso, D. and Skutsch, M. (2006). Community Forest Management as a Carbon Mitigation Option. Bogor: Center for International Forestry Research (CIFOR). from

http://www.cifor.cgiar.org/publications/pdf_files/Books/BMurdiyarso0602.pdf

Nabuurs, G.J., Masera, O., Andrasko, K., et al. (2007). Forestry. In B. Metz, et al. (Eds.), Climate Change 2007: Mitigation. Contribution of Working Group III to the Fourth Assessment Report of the Intergovernmental Panel on Climate Change. Cambridge: Cambridge University Press.

Næss, A. (1973). The Shallow and the Deep, Long-Range Ecology Movement. Inquiry, 16, 151-5.

Noble, I. (2007). Financing Reduced Emissions from Deforestation and Degradation. Paper presented at the 2nd SBSTA Workshop Access 2007.

OCHA (2008a). Ist Situation Report - Bolivia Floods - 23rd of January 2008: United Nations Office for the Coordination of Humanitarian Affairs. from http://www.unicef.org/bolivia/OCHA_SitRep_1_23.Jan.08.pdf 
OCHA (2008b). 13th Situation Report - Bolivia Floods - 7 March 2008: United Nations office for the Coordination of Humanitarian Affairs. Retrieved 28th May 2008, from

http://ochaonline.un.org/OchaLinkClick.aspx?link=ocha\&docId=1087097

Overton, J. (2007). A Personal definition of Development.

Paz, C. and Halloy, S.(2008). Interview on the Development of REDD Incentives in Bolivia. Recorded by Stoppel, J. on the $18 \mathrm{th}$ of January in La Paz.

PICIR (2007). Nobel laureates agree on a global contract: Aposition for a great transformation. Potsdam: Potsdam Institute for Climate Impact Research. Retrieved 22nd of May, 2008, from http://www.nobelcause.de/Potsdam\%20Memorandum_eng.pdf

Pieck, S.K. (2006). Opportunities for transnational indigenous ecopolitics: the changing landscape in the new millennium. Global Networks-a Journal of Transnational Affairs, 6(3), 309-329.

PNCC, P.N.d.C.C. (2006). Mitigación del Cambio Climático. La Paz, Bolivia: Oficina de Desarrollo Limpio, Ministerio de Planificatión del Desarrollo.

Prashad, V. and Ballvé, T. (Eds.). (2006). Dispatches from Latin America: on the frontlines against neoliberalism. Cambridge: South End Press.

Ribera, M. (2008). Interview on the Development of REDD Incentives in Bolivia. Recorded by Stoppel, J. on the 16 th of January in La Paz.

Robertson, N. and Wunder, S. (2005). Fresh tracks in the forests: assessing incipient payments for environmental services initiatives in Bolivia Bogor: Center for International Forestry Research from http://www.cifor.cgiar.org/pes/publications/pdf_files/BRobertson0501.pdf

Schumacher, E.F. (1999). Small is beautiful: a study of economics as if people mattered. Vancouver: Hartley \& Marks Publishers Inc. .

Seifert-Granzin, J.(2008a). Interview on the Development of REDD Incentives in Bolivia. Recorded by Stoppel, J. on the 24 th of January in Santa Cruz.

Seifert-Granzin, J.(2008b). Interview on the progression of the Readiness Mechanism under the FCPF. Recorded by Stoppel, J. on the 11th of June, 2008 in Skype Conference.

Smith, C. (2004). Permaculture: Learning for Sustainable Development. Eingana, $27(1), 12-16$.

Stearman, A.M. (2006). One step forward, two steps back: The Siriono and Yuqui community forestry projects in the Bolivian Amazon. Human Organization, $65(2), 156-166$.

Tauli-Corpuz, V. (2007). Statement on the Announcement of the World Bank Forest Carbon Partnership Facility. Paper presented at the 13th Conference of Parties. Access 2007, from http://carbonfinance.org/docs/UNPFII.pdf.

Thompson, W.I. (Ed.). (1987). GAIA, A Way of Knowing. Great Barrington: Lindisfarne Press. 
Timmons Roberts, J. and Parks, B.C. (2007). A Climate of Injustice. Global Inequality, North-South Politics, and Climate Policy. Cambridge, London The MIT Press.

Ulloa V., G.(2008). Interview on the Development of REDD Incentives in Bolivia. Recorded by Stoppel, J. on the 7th of January in La Paz.

UNDP (2007). Human Development Report 2007/ 2008. New York United Nations Development Programme. Retrieved 21st of June, 2008, from http://hdr.undp.org/en/media/hdr 20072008 en complete.pdf

UNFCCC (2005a). Reducing emissions from deforestation in developing countries: approaches to stimulate action. Paper presented at the 11th Conference of Parties Access 2005a.

UNFCCC (2005b). Report on the Conference of the Parties on its eleventh session, held at Montreal from 28 November to 10 December 2005. Paper presented at the 11th Conference of Parties. Access 2005b.

UNFCCC (2007a). Report on the Second Workshop on Reducing Emissions from Deforestation in Developing Countries Paper presented at the 2nd SBSTA Workshop. Access 2007a.

UNFCCC (2007b). Views on issues related to further steps under the Convention related to reducing emissions from deforestation in developing countries: approaches to stimulate action. Paper presented at the 27 th session of the Subsidiary Body for Scientific and Technological Advice. SBSTA 27. Access 2007b.

UNFCCC (2008a). Reducing emissions from deforestation in developing countries.Retrieved 28th of April, 2008, from http://unfccc.int/methods and science/lulucf/items/4123.php

UNFCCC (2008b). Report of the Conference of the Parties on its thirteenth session, held in Bali from 3 to 15 December 2007. Part two: Action taken by the Conference of the Parties at its thirteenth session Paper presented at the 13th Conference of Parties. Access 2008b.

UNFCCC (2008c). UNFCCC 1st Workshop on Reducing Emissions from Deforestation in Developing Countries

30 August - 1 September 2006 in Rome. Retrieved 8th of May, 2008, from http://unfccc.int/methods_and_science/lulucf/items/3745.php

UNFCCC (2008d). Views on outstanding methodological issues related to policy approaches and positive incentives to reduce emissions form deforestation and forest degradation in developing countries. Submissions of Parties. Paper presented at the SBSTA 28 Access $2008 \mathrm{~d}$.

Vanuatu, R.o. (2007). Reducing Emissions from Deforestation in Developing Countries Retrieved. from http://unfccc.int/files/methods_and_science/lulucf/application/pdf/vanuatu. pdf

Villanueva, J.(2008). Interview on the Development of REDD Incentives in Bolivia. Recorded by Stoppel, J. on the 18th of January in La Paz.

Wachholtz, R.(2008a). Interview on the Development of REDD Incentives in Bolivia. Recorded by Stoppel, J. on the 23 rd of January in Santa Cruz. 
Wachholtz, R. (2008b). 23.01.08. Interview on the Development of REDD Incentives in Bolivia.

Wachholtz, R., Artola, J.L., Camargo, R., et al. (2006). Avance de la deforestación mecanizada en Bolivia. Santa Cruz, Bolivia: Superintendencia Forestal.

Ward, J. (2004). Latin America. Development and Conflict since 1945 (Second Edition ed.). New York: Routledge.

WCED (1987). Our Common Future. Oxford. Oxford University Press: World Commission on Environment and Development.

Weaver, S. (2006). Reducing Emissions from deforestation. In R. Chapman, Bosten, J. and Schwass, M. (Ed.), Confronting Climate Change: Critical Issues for New Zealand (pp. 245-252). Wellington: Victoria University Press.

Weaver, S. (2007). Interview on the Direct Barter Mechanism. Recorded by Stoppel, J. on the 24th of October in Wellington.

Weizäcker, E.U.v. (1994). Earth Politics. London: Zed Books.

Westra, L. and J., L. (Eds.). (1995). Perspectives on Ecological Integrity. Dordrecht: Kluwer Academic Publishers.

Willis, K. (2006). Interviewing. In V. Desai, et al. (Eds.), Doing Development Research (pp. 145-152). London: SAGE Publications.

Wilson, S., Breitkopf, S., Alley, P., et al. (2007). FCPF Consultation with NGOs. From The Rainforest Foundation, Global Witness, Forest Monitor and Greenpeace International

to Carbon Finance Unit, World Bank. Retrieved 10th of March, 2008, Access 2007 , from

http: / / carbonfinance.org/Router. cfm?Page $=$ FCPF \&FID $=34267 \& I t e m I D=34267 \& \mathrm{ft}=\mathrm{DoC}$ Lib\&CatalogID $=37856$.

WMO (2008). El Niño/ El Niña Update: World Meteorological Organization. Retrieved 22nd of May 2008, from http://www.wmo.ch/pages/prog/wcp/wcasp/documents/El_Nino_Feb08_Eng.pdf

WorldBank (2007). Bolivia Data Profile.Retrieved 28th of May, 2008, from http://devdata.worldbank.org/external/CPProfile.asp? SelectedCount ry=BOL\&CCO $\mathrm{DE}=\mathrm{BOL} \& \mathrm{CNAME}=\mathrm{BOl}$ ivia\&PTYPE$=\mathrm{CP}$

Worldbank (2008). Bolivia Country Brief.Retrieved 28th of May, 2008, from http://web.worldbank.org/WBSITE/EXTERNAL/COUNTRIES/LACEXT/BOLIVIAEXTN/0, me nuPK:322289 pagePK:141132 piPK:141107 theSitePK:322279,00.html

Wunder, S. (2006). Are direct payments for environmental services spelling doom for sustainable forest management in the tropics? Ecology and Society, $11(2)$.

Wunder, S. (2007). The efficiency of payments for environmental services in tropical conservation. Conservation Biology, 21(1), 48-58.

WWI, T.W.I. (2006). Vital Signs 2006-2007, The Trends That Are Shaping Our Future. New York: W. W. Norton \& Company, Inc. 
Zoellick, R. (2007). Launch of the Forest Carbon Partnership Facility $(F C P F)$. Paper presented at the 13th CP of the UNFCCC. Access 2007, from http://carbonfinance.org/docs/WorldBank.pdf. 


\begin{abstract}
Annexes
Hoja informativa del participante

\section{Proyecto: Estudio exploratorio de una cartera de intercambio directo en Bolivia}

Hola, mi nombre es Jannes. Soy estudiante de Licenciatura en Estudios sobre Desarrollo internacional de Victoria University of Wellington (Universidad Victoria de Wellington), Aotearoa / Nueva Zelanda. Estudios sobre Desarrollo combina las áreas de Geografía Humana, Gestión Ambiental, Antropología y Ciencias Sociales, Economía y Relaciones Internacionales para generar una solución para el futuro justa, pacífica, próspera y ecológicamente sostenible en el planeta Tierra. El principal objetivo de la tesis de mi investigación es encontrar soluciones justas que determinen como la protección de los bosques se puede implementar en las estrategias actuales internacionales del cambio climático.
\end{abstract}

La deforestación es responsable del 20 a 25\% de las emisiones mundiales de CO2. Además, ha contribuido a la vasta extinción de la biodiversidad de los bosques y la explotación de los habitantes de los mismos. Pero también ofrece a los habitantes de los bosques la oportunidad de crecimiento económico básico. La urgencia de evitar a gran escala las emisiones de deforestación y la urgencia de encontrar soluciones sostenibles y justas hizo que me interesara en las negociaciones internacionales en curso sobre las estrategias de cambio climático.

Con ello se ofrece la oportunidad de desarrollar nuevas ideas.

El Gobierno de Vanuatu (un pequeño estado insular del Pacífico), pero parte de la Coalición de las naciones de lluvias tropicales ha pedido incentivos para reducir la deforestación en su país. Ha establecido, con la ayuda de mi Universidad, un enfoque que se centra en las necesidades para lograr la disminución de la deforestación. El enfoque se basa en la idea de los intercambios directos entre entidades ambientalmente ricas que protegen los ecosistemas de bosques y entidades económicamente ricas que pueden proporcionar el apoyo necesario y las medidas de protección para ello. Esta idea desarrollada por el profesor Sean Weaver reconoce los cuidados y la protección de los ecosistemas de bosques intactos y, promueve una mayor valoración internacional de este "servicio". Además, ofrece la oportunidad para que los países económicamente ricos reembolsen por la explotación de los bosques y la herencia del impacto climático. Dichos reembolsos podrían ser la reducción de la deuda, apoyo técnico, desarrollo de la comunidad o incentivos en cuanto a comercio justo se refiere. Estos deben ser lo que la entidad identifique como necesario para la protección de los ecosistemas de bosques identificados sin crear desventajas económicas. Debido a que este enfoque se basa en la disposición voluntaria de las entidades económicamente ricas para redirigir la riqueza a nivel mundial para la prosperidad común, este enfoque tiene un carácter ambiguo.

Pero también la voluntad de las entidades de bosques ecológicamente ricos debe establecerse para crear carteras de intercambio, con el propósito de generar una oferta a quien pudiera estar interesado.

Como parte de mi tesis de Licenciatura, me gustaría explorar e identificar las opiniones de los bolivianos con respecto a este planteamiento directo de intercambio. Quiero explorar la posible zona de bosques de Bolivia que podría, potencialmente, ser protegida, quiero examinar la manera en la que estos bosques podrían ser utilizados sosteniblemente y quiero recoger ideas bolivianas sobre lo que Bolivia podría pedir como reembolsos por el esfuerzo a gran escala de la protección de los bosques de Bolivia. Con la combinación de esta información, quiero descubrir las posibilidades para crear una cartera de relación directa de intercambio de valores ecológicos de Bolivia.

El formulario de consentimiento del participante es para asegurar de que usted está feliz de comprometerse y participar en mi investigación. En virtud de todas las circunstancias, me gustaría asegurarme de que usted como voluntario participante de mi investigación está consciente de lo que ocurre con la información que pueda compartir conmigo. Esto es también de interés de mi Universidad y de la Comisión de Ética Humana. 
Después de compartir conmigo la información, ésta será mantenida bajo resguardo y sólo podrá estar disponible para mis supervisores los profesores John Overton

(john.overton@vuw.ac.nz) y Sean Weaver (sean.weaver@vuw.ac.nz). Una vez terminada mi tesis será revisada por otros dos profesores. Después de ello estarán disponibles para otros estudiantes en la biblioteca de Victoria University of Wellington (Universidad de Victoria en Wellington). También es posible que publique los resultados como informe resumido o en forma de artículo en un periódico o revista. Espero que usted esté de acuerdo con las condiciones mencionadas en el formulario de consentimiento y que esté dispuesto a elegir una de las opciones sobre cómo manejar su información.

Si tiene más preguntas, preocupaciones o le gustaría recibir más información sobre mi investigación, por favor no dude en ponerse en contacto conmigo. Le agradezco mucho su ayuda y su contribución a esta investigación.

\section{Contactos:}

Correo postal: Jannes Stoppel

School of Geography , Environment and Earth Sciences (Escuela de Geografía, Ciencias de la Tierra y el Medio Ambiente) Victoria University (Universidad Victoria)

Wellington 6140

PO Box 600

Aotearoa / New Zealand (Nueva Zelanda)

Móvil: +64-2102399677

Teléfono: +64-4-4636397

E-mail: jannes.stoppel@mac.com

Skype: jannes.stoppel 


\section{Formulario de consentimiento del participante}

\section{Proyecto: Estudio exploratorio de una cartera de intercambio directo para Bolivia}

Estoy de acuerdo en participar en el proyecto de investigación denominado "Estudio exploratorio de una cartera de intercambio directo de valores ecológicos para Bolivia" realizado por Jannes Stoppel como informante. Recibí una ficha de información sobre el proyecto de investigación y entiendo esta información. Se me ha ofrecido la oportunidad de preguntar sobre temas más específicos y he recibido contestación a todas mis interrogantes. Entiendo que puedo retirar mi participación o cualquier información que haya proporcionado a esta investigación antes de la finalización de la misma (con fecha de 31 de junio del año 2008) sin necesidad de esgrimir ningún tipo de razones. Mis datos de contacto se encuentran en la ficha de información. Entiendo que las entrevistas se realizarán con consentimiento oral y serán grabadas en audio lo que me permitirá solicitar que el dictáfono sea desactivado en cualquier momento. Además, estas grabaciones pueden ser transcritas a formato escrito y tengo la oportunidad de revisar y modificar la información registrada después. Entiendo que después de la conclusión de este proyecto de investigación todas las grabaciones y sus respectivas transcripciones se mantendrán en forma segura y confidencial y serán destruidas por el investigador 1 año después del término de este proyecto de investigación.

Por favor, seleccione UNA de las alternativas con la que esté de acuerdo:

- Doy mi consentimiento para que la información o las opiniones proporcionadas se mantengan completamente confidenciales, que no sean verbalmente propagadas ni utilizadas en cualquier forma documentada o grabada. Los datos proporcionados sólo se utilizarán para ampliar y profundizar la comprensión del investigador de los temas tratados.

- Doy mi consentimiento para que la información o las opiniones proporcionadas sólo sean utilizadas y publicadas anónimamente. La información sólo se vinculará a una vaga definición de tiempo y lugar que no le permitirán ser identificables.

- Doy mi consentimiento para que mi identidad no permanezca confidencial. Jannes Stoppel, Victoria University of Wellington (Universidad Victoria de Wellington), y todas las publicaciones que utilizan material de este proyecto de investigación tienen mi permiso para identificarme públicamente por mi nombre y usar la transcripción de la entrevista conmigo como una representación exacta de lo que he dicho con la presentación total de mis datos personales, incluidos tiempo y lugar de referencia conectado a mi grupo, departamento u organización. 


\section{Declaración de confidencialidad}

\section{Proyecto: Estudio exploratorio de una cartera de intercambio directo para Bolivia}

Estoy agradecido de que esté dispuesto a participar en mi proyecto de investigación. Si ha compartido conmigo información ésta se mantendrá en forma confidencial y sólo será compartida con mi supervisor Prof John Overton (john.overton@vuw.ac.nz) y potenciales traductores y transcriptores, que también deberán firmar un formulario de completa confidencialidad. Una vez analizados los resultados de mi investigación y mi tesis sea completada, estos serán revisados por dos profesores diferentes. Después de ello, serán publicados en la biblioteca de Victoria University of Wellington (Universidad Victoria de Wellington). También es posible que yo publique mis resultados en forma de artículo en un periódico o revista. Además, esta declaración le asegura que usted puede retirar su participación y la información que proporcionó en cualquier momento, pero antes de la fecha de publicación (con fecha de 1 de junio del año 2008), sin necesidad de esgrimir ningún tipo de razones. Después de ello, estaré obligado a destruir toda la información proporcionada por usted o su organización. Muchas gracias por su ayuda.

Jannes Stoppel

Correo postal:

Teléfono:

e-mail:

skype:
School of Earth Sciences (Facultad de Ciencias de la Tierra) Victoria University of Wellington (Universidad Victoria de Wellington) PO Box 600 Aotearoa / New Zealand (Nueva Zelanda)

- Estoy de acuerdo en que la información recopilada se m antendrá completamente confidencial, no será verbalmente propagada ni será utilizada en cualquier forma documentada o grabada. Los datos proporcionados sólo se utilizarán para ampliar y profundizar la comprensión del investigador de los temas tratados.

- Estoy de acuerdo en que la información y las opiniones recopiladas sólo se utilizarán y publicarán anónimamente. Toda la información puede ser vinculada a una vaga definición de tiempo y lugar que no le permitirán ser identificables.

- Por este medio le aseguro que toda la información, todos los datos y todas las opiniones reunidas serán manejados con mucho cuidado y sensatez y que todos los documentos y la información grabada se almacenarán de la forma más segura posible en todo momento. 


\section{Declaración de no divulgación}

\section{Proyecto: Estudio exploratorio de una cartera de intercambio directo para Bolivia}

He sido empleado por Jannes Stoppel para la transcripción o traducción de la información relacionada al proyecto de investigación "Estudio exploratorio de una cartera de intercambio directo para Bolivia". Entiendo que estos datos deben ser manejados con sumo cuidado. Comprendo que la confidencialidad es importante para todos quienes participan en este proyecto. Me comprometo a no discutir la información de las entrevistas o los datos proporcionados transcritos o traducidos con ninguna otra persona que no sea Jannes Stoppel. También me comprometo a no revelar los nombres o identidades de ninguno de los participantes en el proyecto. Entiendo que al romper mi promesa pongo en riesgo la reputación e incluso el bienestar de los informantes y el investigador.

- Por favor marque si desea recibir un resumen de mi investigación después de su término. Si es así, por favor proporcione los detalles de su correo postal o electrónico al reverso de este formulario. 


\section{Participant Information Sheet}

\section{Project: Exploratory Study of the Developments of REDD incentives in Bolivia}

Hola, my Name is Jannes. I'm a Masters of Development Studies student at Victory University in Wellington Aotearoa/ New Zealand. I have been active in several social and environmental movements in Europe Aotearoa/ NZ and have worked as an independent researcher for Environmental NGOs like Greenpeace for the last 5 years. Now I work on my thesis to finish my degree in Development Studies.

One of my main interest has been the protection of old growth forests and the support of sustainable forest use practices around the globe. Deforestation has not only contributed to the vast extinction of forest biodiversity, the exploitation of forest inhabitants but also to the increasing impact of the global climate system through emissions from deforestation. The urgency to find sustainable and fair solutions to avoid deforestation got me interested in the current international climate change strategies.

These offer the opportunity to develop new Ideas. The Government of Vanuatu (of a small Pacific Island state) has called for action incentives to reduce deforestation in its country. It has, with help of my University, established an approach that focuses on the needs to achieve the prohibition of deforestation. The idea is based on direct barter exchanges between the environmentally rich entities that protect forest ecosystems and economically rich entities that can supply the needed support and measures for this protection. This idea developed by Prof. Sean Weaver acknowledges the care-taking and protection of intact forest ecosystems and promotes a higher international valuation of this 'service'. Further it offers the opportunity to exchange for economically rich countries to reimburse for their forest exploiting and climatic impacting heritage. These reimbursements could be reduction of debt, technical support, community development incentives or fair trade deals. These could be whatever the protecting entity identifies as needed for the protection of vast forest ecosystems without creating economic disadvantages. From my point of view it is an ambiguous idea that has great potential. But it is also opposed to systematic economical imbedded climate mitigation strategies that are supported by the historically most emitting and most profiting economic powers.

As part of my Masters degree Thesis I want to explore and identify what Bolivian opinions are on this direct barter approach. I got to know that Bolivia is one of the countries that have also called for urgent action to find incentives that reduce emissions from deforestation. I learned about Bolivia's current situation and its possibilities to develop incentives that protect forest areas from deforestation. I will explore the possible Bolivian forest area that could potentially be protected and further I will look into how these forest could be sustainable used. I want to gather Bolivian ideas on what Bolivia could demand as reimbursements for a national Bolivian forest protection effort. Combining these information, I want to find out the possibilities to create a direct barter exchange portfolio of Bolivia's ecological values for further promotion in current international climate change mitigation efforts. To get a broad overview of Bolivian opinions I will try to talk to Government officials, University researchers, students, NGO representatives, Community groups and indigenous representatives. As part of this research process I will talk to people like you about your opinion on national forest protection efforts if they are done in a way that allows sustainable community development through the support of small-scale sustainable forest use.

The Consent Form is to assure that you are happy to commit and participate in my research. Under all circumstances I want to make sure that you as a voluntary participant of my research are aware about what happens to the information you might share with me. This is also in the interests of my University and it's Human Ethics Committee.

After you have shared information with me they will be kept confidentially and will only be shared with my supervisors Prof. John Overton (john.overton@vuw.ac.nz) and Prof. Sean Weaver (sean.weaver@vuw.ac.nz). Once my thesis is it will be viewed by two different 
professors. It will than be published and made available for other students in the Victoria University library in Wellington. It is also possible that I publish the results in article form in a journal or magazine. I hope that you can agree to the terms mentioned In the consent form and that you are willing to choose one of the options on how I handle your information.

If you have any further questions, concerns or you would like to receive more information on my research please don't hesitate to contact me. I thank you very much for your help and your contribution to my research.

$\begin{array}{ll}\text { phone: } & \text { +64-4-4757777 } \\ \text { e-mail: } & \text { jannes.stoppel@mac.com } \\ \text { skype: } & \text { jannes.stoppel } \\ \text { mail: } & \text { Jannes Stoppel } \\ & \text { School of Earth Sciences } \\ & \text { Victoria University Wellington } \\ & \text { PO Box 600 } \\ & \text { Aotearoa/ New Zealand }\end{array}$




\section{Participant Consent Form}

\section{Project: Exploratory Study of the development of REDD incentives in Bolivia}

I agree to participate on the 'Exploratory study of a Direct Barter Portfolio for Bolivia's Ecological Values' research project by Jannes Stoppel as an informant. I have been given an information sheet about the research project and I understand this information. I have been offered the opportunity for further questions and these have been answered to my full satisfaction. I understand that I may withdraw my participation or any information I have provided from this research before completion ( $1^{\text {st }}$ of June 2008) without the need to provide any reasons. Contact details are shown on the information sheet.

I understand that interviews will be, if given verbal consent, recorded on audiotape whereby I may request to have the Dictaphone turned off at any time. Further these recordings may be transcribed into written form. I have the opportunity to review and modify the recorded information afterwards. I understand that after completion of this research project all recorded and transcribed information will be kept securely and confidentially and will be destroyed by the researcher 1 year after completion of this research project.

\section{Please mark and therefore agree with $\underline{\mathrm{ONE}}$ of the following options:}

I consent that my provided information or opinions will be kept completely confidential, will not be verbally spread and will not be used in any documented or recorded form. The provided data will only be used to extend and broaden the researcher's understanding of the researched issues.

$\square$ I consent that my provided information or opinions are only to be used and published anonymously. Your information will be linked only to a vague definition of time and place that will not allow you to be identifiable.

I consent that my identity will not remain confidential. Jannes Stoppel, the Victoria University of Wellington, and any publications which use material from this research project have my permission to publicly identify me by name and use the transcript of the interview with me as an accurate representation of what I have said under full presentation of my personal details, including time place and reference to my connected group, department or organization. 


\section{Statement of Confidentiality}

\section{Project: Exploratory Study of the development of REDD incentives in Bolivia}

I'm grateful that you are willing to participate in my research project. If you have shared information with me they will be kept confidentially and will only be shared with my supervisor Prof. John Overton (john.overton@vuw.ac.nz) and potential translaters and transcribers who will also sign a form of complete confidentiality. Once I analyse my research outcome and my thesis is completed it will be viewed by two different professors. It will than be publicised in the Victoria University library in Wellington. It is also possible that I publish my results in article form in a journal or magazine.

Further this statement assures you that you may withdraw your participation and your provided information at any time, but before publication date $\left(1^{\text {st }}\right.$ of June 2008), without the need to provide any reasons. I will than be obligated to destroy all information provided by you or your organization. Thank you very much for your help.

Mail: Jannes Stoppel

School of Earth Sciences

Victoria University Wellington

PO Box 600

Aotearoa/ New Zealand

\author{
Phone: \\ e-mail: \\ skype: \\ $+64-2102399677$ \\ jannes.stoppel@mac.com \\ jannes.stoppel
}

I agree that the gathered information will be kept completely confidential, will not be verbally spread and will not be used in any documented or recorded form. The provided data will only be used to extend and broaden the researcher's understanding of the researched issues.

I agree that the gathered information or opinions are only used and published anonymously. All your provided information might be linked only to a vague definition of time and place that will not allow you to be identifiable.

Hereby I assure you that all information, all data and all gathered opinions will be handled with great sensitivity and care and that all documented and recorded information will be as securely stored as possible at all times. 


\section{STATEMENT OF NON-DISCLOSURE}

\section{Project: Exploratory Study of the development of REDD incentives in Bolivia}

Jannes Stoppel has employed me for the transcription or translation of information connected to the 'Exploratory Study of a Direct Barter Portfolio for Bolivia' research project. I understand that these information have to be handled with great sensitivity. I understand that confidentiality is important to everyone taking part in this project. I promise that I will not discuss the information of the interviews or the provided data that I have transcribed or translated with anyone other than Jannes Stoppel. I also promise that I will not reveal the names or identities of any of the project participants to anyone. I understand that by breaking my promises I might risk the reputation or even the wellbeing of informants and the researcher.

Please tick if you would like to receive a summary of my research after its completion. If so please provide your mail or e-mail details on the back of this form. 